
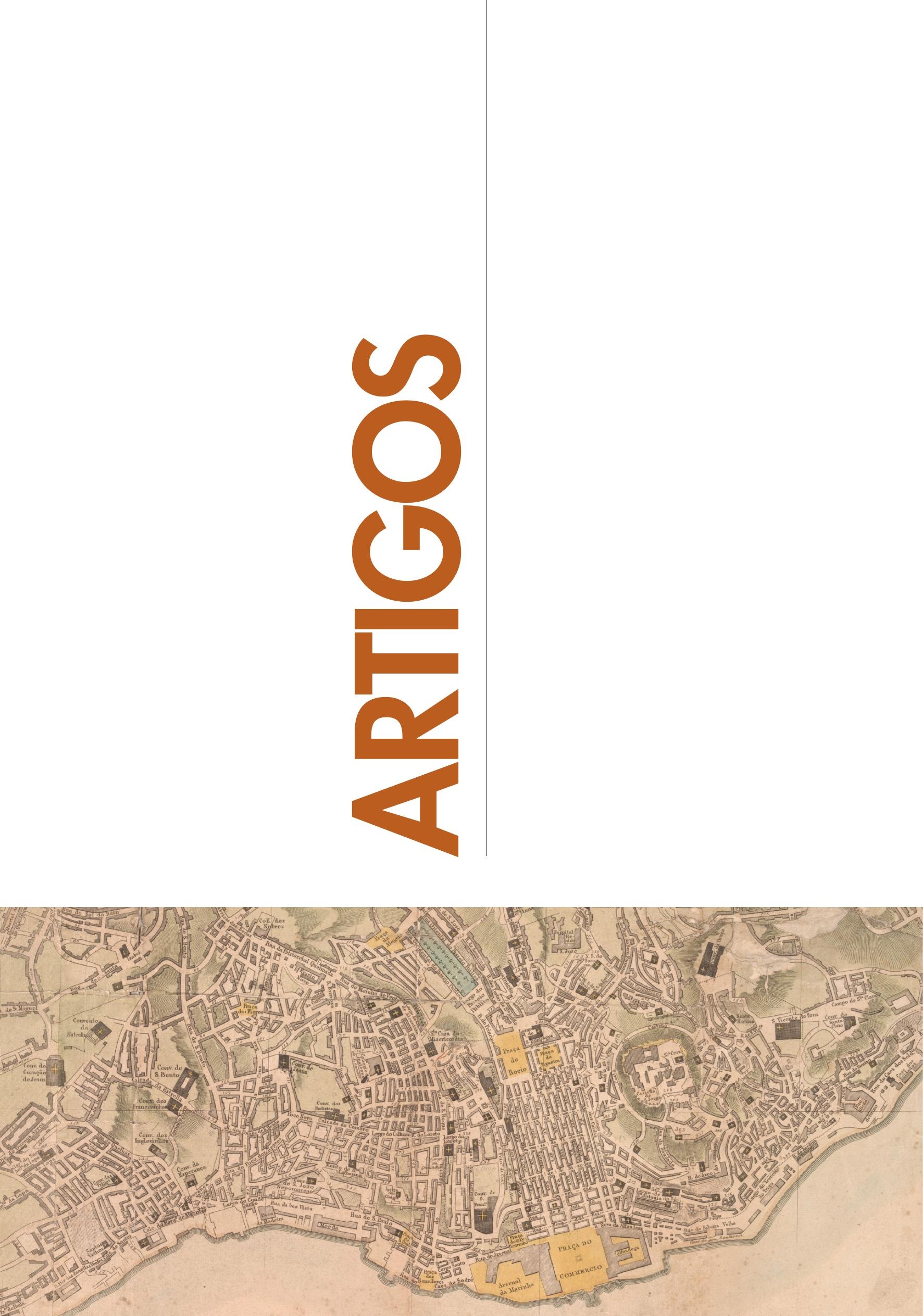


\section{Página anterior:}

Planta da cidade de Lisboa e de Belém : publicada em Londres e copiada em Lisboa em 1837. Lisboa: Imprensa de Candido Antonio da Silva Carvalho, 1837. Biblioteca Nacional de Portugal. 


\section{Resumo}

Contatos

Aldair Rodrigues

Rua Cora Coralina, 100

13083-896 - Campinas - São Paulo - Brasil rodriguesaldair@gmail.com

Fernanda Olival

Colégio do Espírito Santo

Largo dos Colegiais, 2

7000-803 - Évora - Portugal

fernanda.olival@gmail.com
REINÓIS VERSUS

NATURAIS NAS DISPUTAS

PELOS LUGARES

ECLESIÁSTICOS DO

ATLÂNTICO PORTUGUÊS:

ASPECTOS SOCIAIS E POLÍTICOS (SÉCULO XVIII)*

\author{
Aldair Carlos Rodrigues** \\ Universidade Estadual de Campinas \\ Campinas - São Paulo - Brasil \\ Fernanda Olival $^{* * *}$ \\ Universidade de Évora; Cidehus \\ Évora - Portugal
}

Este artigo elege a clivagem naturais da terra / reinóis como vetor principal de análise das características do clero presente no espaço atlântico português, enfocando os clérigos seculares dos Açores, da Madeira e do Brasil durante o século XVIII. Identifica os traços principais do perfil dos sacerdotes que se habilitaram no Santo Ofício e a origem dos titulares das prebendas dos cabidos do centro-sul brasileiro: Rio de Janeiro, São Paulo e Minas Gerais. Demonstra-se que acesso aos lugares do poder eclesiástico foi permeado por uma série de dinâmicas sociais e políticas, intermediando as relações entre a Coroa, as elites locais e segmentos intermédios.

\section{Palavras-chave}

Clero - hierarquias sociais - naturalidades.

* Investigação desenvolvida no âmbito dos projetos: PTDC/HIS-HIS/118227/2010 - FCT, Portugal (Compete/Qren/Feder - FCOMP-01-0124-Feder-010520); UID/HIS/0057/2013 (POCI-01-0145FEDER-007702).

* Doutor pelo Programa de Pós-graduação em História Social da Faculdade de Filosofia, Letras e Ciências Humanas da Universidade de São Paulo. Foi post-doctoral fellow na Yale University/ Council on Latin American and Iberian Studies, onde coordenou a Brazil Lecture Series (2015). Professor do Departamento de História do Instituto de Filosofia e Ciências Humanas.

*** Doutora pela Universidade de Évora, onde leciona desde 1991. Diretora do Centro Interdisciplinar de História, Culturas e Sociedades e coordenadora do projeto Intergroups: grupos intermédios em Portugal e no Império português: as familiaturas do Santo Ofício (c. 1570-1773). Trabalha sobre ordens militares, Inquisição, história social. 


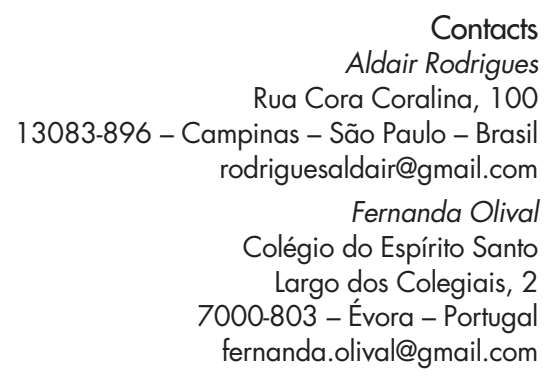

Contacts

Aldair Rodrigues

Rua Cora Coralina, 100

13083-896 - Campinas - São Paulo - Brasil rodriguesaldair@gmail.com

Fernanda Olival

Colégio do Espírito Santo

Largo dos Colegiais, 2

7000-803 - Évora - Portugal

fernanda.olival@gmail.com

\section{DISPUTING THE ECCLESIASTICAL}

APPARATUS IN THE

PORTUGUESE ATLANTIC

WORLD: SOCIAL AND

POLITICAL ASPECTS

(EIGHTEENTH CENTURY)

\author{
Aldair Carlos Rodrigues \\ Universidade Estadual de Campinas \\ Campinas - São Paulo - Brasil
}

Fernanda Olival

Universidade de Évora; Cidehus

Évora - Portugal

\begin{abstract}
This article analyzes the role played by place of birth (Portugal/overseas) to characterize the existing clergy in the Portuguese Atlantic territories, while focusing on the secular clergy of Azores, Madeira, and Brazil during the eighteenth century. It examines the main characteristics of the priests who became agents of the Inquisition, and of those who became members of the cathedrals chapters (as canon or dignity) in Rio de Janeiro, São Paulo, and Minas Gerais. Social and political dynamics played an important role toward the admittance into such ecclesiastical offices, thus influencing the relationship established between the Crown and local elites, besides others social groups.
\end{abstract}

\title{
Keywords
}

Clergy - social hierarchies - birthplace.

Obs: Principais abreviaturas usadas: ACM-SP - Arquivo da Cúria Metropolitana de São Paulo; AEAM - Arquivo Eclesiástico da Arquidiocese de Mariana; AHU - Arquivo Histórico Ultramarino; AMCM-RJ - Acervo Musical do Cabido Metropolitano do Rio de Janeiro; ANTT - Arquivo Nacional da Torre do Tombo; ASV - Arquivo Secreto do Vaticano; AUC - Arquivo da Universidade de Coimbra; BA - Biblioteca da Ajuda; BNP - Biblioteca Nacional de Portugal; HSO - Habilitações do Santo Ofício; LC - Library of Congress; MCO - Mesa de Consciência e Ordens; RJ - Rio de Janeiro. 


\section{Introdução}

A historiografia luso-brasileira tem tendencialmente subestimado os órgãos do poder da Igreja e seus recursos simbólicos e materiais para a compreensão das dinâmicas sociais e políticas do Antigo Regime. Em parte, este enquadramento se deve, por um lado, ao entrave que representa o vocabulário eclesiástico; por outro, à separação entre Igreja e Estado na ordem liberal dos séculos XIX e XX. Inconscientemente, projeta-se para a época moderna esta disjunção, o que influencia o formular de questões em torno dos poderes eclesiásticos. Importa rever esta postura e olhar com alteridade para aquele contexto.

Este artigo elege como tópico de análise, à partida, a naturalidade do clero secular presente no espaço atlântico português. Privilegia as dioceses do centro-sul do Brasil e as ilhas atlânticas, já que nem todas as áreas geopolíticas deste vasto oceano tinham os mesmos ritmos e o mesmo perfil socioeconômico. Foram selecionados os territórios portugueses nos quais a formação das hierarquias sociais inspirava-se de perto nos ideais de estratificação metropolitanos e a colonização articulava um grande mosaico socioeconômico, abrangendo comércio negreiro, roças e exportação de commodities.

Procura-se analisar a clivagem naturais da terra/reinóis e os seus significados alargados, incluindo os sociais e os políticos, no século XVIII. Estes atributos apareciam sempre referidos pelos próprios atores sociais e os seus coevos num contexto de disputa por interesses e eram feitos equivaler a locais de nascimento. ${ }^{1}$

Usa-se a esfera eclesiástica como âmbito de observação, tanto pela sua complexidade como pela grande capacidade de territorialização de seu aparato institucional. Tais características viabilizam o estabelecimento de comparações (sobretudo com funções heurísticas e de contraste) ${ }^{2}$ em diferentes níveis entre os vários locais considerados. Poder-se-ia também fazer o mesmo para os ofícios militares ou outros aparatos institucionais.

Ao longo do texto serão adotadas duas escalas de observação:

\footnotetext{
1 Tamar Herzog fez notar como este tipo de atributos só era apontado quando havia interesses a defender e como, no caso espanhol, nem sempre correspondia ao local de nascimento. HERZOG, Tamar. Naturales y extranjeros: sobre la construcción de categorías en el mundo hispánico. Cuadernos de Historia Moderna, vol. 10, Madri, 2011, p. 23, 31.

2 HAUPT, Heinz-Gerhard. Comparative history - a contested method. Historisk Tidskrift, vol. 127, n. 4, 2007, p. 697-716. KOCKA, Jürgen. Comparison and beyond. History and Theory, vol. 42, n. 1, 2003, p.39-44.
} 
(I) Num primeiro momento examinam-se as origens institucionais dos membros do clero que se habilitaram como comissários do Santo Ofício. Procura-sedelinearaconfiguraçãodarededopontodevistadasorigensdos seusmembros eaveriguaroimpactoda naturalidadeem sua configuração.

(II) Em seguida, passamos a estudar os cabidos das catedrais (Rio de Janeiro, São Paulo, Mariana, Angra e Funchal), abordando a naturalidade dos prebendados e o significado da clivagem naturais / reinóis nas disputas pelo controle destes lugares por parte de grupos locais.

No primeiro passo, predominará a análise quantitativa e serial dos dados coletados nas habilitações do Santo Ofício para identificar o perfil do clero. Já a segunda parte do artigo, a mais extensa, será constituída principalmente pela análise qualitativa de documentos variados que revelem o teor da ambição dos naturais do ultramar em influenciar o acesso ao aparato eclesiástico.

Por meio destes percursos analíticos, o artigo pretende trazer contributos para a compreensão do papel desempenhado pelos poderes eclesiásticos no processo de configuração das hierarquias sociais no Império atlântico português em diferentes conjunturas. Além disso, busca esclarecer importantes aspectos políticos subjacentes ao provimento dos postos da Igreja, no âmbito do padroado da Ordem de Cristo.

À partida, a hipótese central é que os lugares do poder eclesiástico e inquisitorial desempenharam um papel muito relevante na formação e consolidação das elites locais e, numa perspectiva mais alargada, na configuração dos grupos intermédios. Esses grupos referidos seriam coincidentes nos espaços atlânticos? Um grupo e outro invocariam de igual forma a clivagem naturais / reinóis ou silenciavam-na? Teria o tópico o mesmo peso em todos os territórios considerados? Eis assim o roteiro de questões a que este artigo pretende responder.

\section{Clérigos habilitados na Inquisição}

\section{a) Naturalidades}

Não dispomos de levantamentos abrangentes e completos acerca da naturalidade do clero da América portuguesa ou de outros locais do Império marítimo português. Uma maneira de ultrapassar esta lacuna e tentar uma aproximação global quanto a este tópico para o contexto setecentista é usar os dados presentes nas habilitações dos clérigos residentes quando se habilitavam ao cargo de comissário do Santo Ofício. Reconstituindo a rede na sua globalidade, há condições para verificar as variações regionais e as 
características do clero em diferentes conjunturas. No entanto, é importante apontar que tendencialmente a Inquisição admitia como comissários os sacerdotes mais proeminentes da hierarquia da Igreja e quase sempre, no caso do clero secular, aqueles que possuíam benefícios eclesiásticos efetivos (fossem cargos vitalícios nos cabidos ou nas igrejas paroquiais) ou com um bom nível de rendimento. Portanto, apesar de abrangente e da grande riqueza das informações que os processos fornecem, a amostra não abarca a totalidade eclesiástica em razão do viés apontado. Para superar esta limitação, no tópico seguinte, a escala de análise será recortada para os cabidos (centro-sul do Brasil e das ilhas), independente de seus membros terem entrado para os quadros do Santo Ofício ou não. Este procedimento viabiliza uma análise mais abrangente e densa acerca da elite eclesiástica da área atlântica apontada.

No século XVIII, a maior parte dos comissários habilitados em qualquer um dos três espaços considerados provinha das fileiras do clero secular, sobretudo do segmento paroquial. ${ }^{3}$ No Brasil, 23 destes 60 fizeram parte também do oficialato episcopal, quase todos nas vigararias da vara.

Em seguida, aparecem os elementos pertencentes aos cabidos catedralícios. Esta hierarquia é, porém, mais complexa. Na realidade, este último setor tinha uma presença fulcral. Efetivamente trata-se de um número elevado, tendo em linha de conta que o clero catedralício era proporcionalmente muito menor que o clero das paróquias. Entre os capitulares, no Brasil, ainda havia 22 que cumpriram simultaneamente funções nas instituições diocesanas, sobretudo como vigários gerais e provisores; um conjunto de 34 agentes não possuía benefícios colados, mas tinha provisão para desempenhar atividades importantes nas instâncias dos auditórios eclesiásticos (vigararia da vara e vigararia geral) ou em outros postos do governo diocesano.

Na Madeira, durante a primeira metade de Setecentos, eram os capitulares que dominavam em exclusivo o lugar de comissário, com uma única

\footnotetext{
3 Além das qualidades exigidas para todos os postos inquisitoriais - ser cristão-velho, não ter nenhum ascendente condenado anteriormente pela Inquisição, ter bom estilo de vida e costumes -, os candidatos ao cargo de comissário precisavam ser "pessoas eclesiásticas, de prudência e virtude conhecida, e achando-se letrados serão preferidos". As principais funções dos comissários eram ouvir testemunhas nos processos de réus e nas habilitações de agentes inquisitoriais; cumprir mandados de prisão com o auxílio dos familiares; vigiar os condenados que cumprissem pena de degredo nas áreas de sua atuação e transmitir denúncias ao tribunal; distribuir os editais que todos os anos deviam ser lidos nas paróquias. Enfim, deveriam estar disponíveis para executar as ordens do Santo Ofício. Dos comissários e escrivães de seu cargo. Reg. 1640, livro I, título XI. Regimentos do Santo Ofício português. Revista do IHGB, Rio de Janeiro, n. 392, jan/dez 1996, p. 495-1020.
} 
exceção: José Martins de Faria, que recebeu a provisão de comissário seis meses antes de ser apresentado como cônego da Sé do Funchal. ${ }^{4}$ Seis meses, note-se bem. O quadro só se alterou na segunda metade da centúria. Nos Açores, na ilha Terceira, todos os comissários aprovados e encartados eram cônegos. Era nas restantes ilhas, onde não havia cabido catedralício, que o clero das paróquias pontificava. No entanto, conforme já advertiu Paulo Drumond Braga, na Terceira, em S. Miguel e no Faial, era inerente ao cargo de reitor da Companhia de Jesus exercer as funções de comissário, mesmo sem carta. ${ }^{5}$ Tendência semelhante foi encontrada por Bruno Feitler no Maranhão. ${ }^{6}$

No Brasil, para um grupo de 57 comissários, ou não foi possível identificar os seus vínculos institucionais com base nos processos de habilitação ou, por exemplo, viviam abastadamente nos engenhos das suas famílias, sem qualquer ligação sólida com instituições eclesiásticas. ${ }^{7}$

\section{Tabela 1}

Filiação eclesiástica no momento da aprovação como comissários do Santo Ofício (1701-1800)

\begin{tabular}{|c|c|c|c|}
\hline Tipo de clero & Brasil & Madeira & Açores \\
\hline Cabido & 52 & 11 & 7 \\
\hline Clero paroquial & 60 & 13 & 8 \\
\hline Clero regular & 34 & 1 & 2 \\
\hline Outros & 57 & 3 & 0 \\
\hline Total & 203 & 28 & 17 \\
\hline
\end{tabular}

Fonte: ANTT, HSO.

Em qualquer dos territórios estudados, das ordens religiosas saiu um número pequeno de agentes. Apesar de tudo, era no vasto Brasil que tinham maior presença no cargo, se se considerar que a maioria dos padres jesuítas que atuaram nos Açores não estava formalmente encartada. ${ }^{8}$

\footnotetext{
${ }^{4}$ ANTT. Inquisição de Lisboa, livro 114, f. 212; ANTT. Chancelaria da Ordem de Cristo, livro 243, f. 396.

5 BRAGA, Paulo Drumond. A Inquisição nos Açores. Ponta Delgada: Instituto Cultural, 1997, p. 28.

${ }^{6}$ FEITLER, Bruno. Nas malhas da consciência: Igreja e Inquisição no Brasil (Nordeste, 1640-1750). São Paulo: Alameda, Phoebus, 2007, p. 128, 153.

7 ANTT, HSO.

${ }^{8}$ Para uma visão de todos os reitores jesuítas que chegaram a atuar em nome do Santo Ofício nos Açores ver BRAGA, Paulo Drumond, op. cit., p. 38-48.
} 
Naquele território, considerando o clero globalmente e do ponto de vista geográfico, três capitanias se destacavam com comissários de sua própria terra: Pernambuco, Bahia9 e Rio de Janeiro. Os reinóis tinham um peso relevante apenas em Minas Gerais e no Maranhão. Nesta última, eram poucos em números absolutos: apenas sete agentes, dos quais três eram do reino.

\section{Tabela 2}

\section{Naturalidade/ mobilidade dos comissários (com processos de habilitação)}

\begin{tabular}{|c|c|c|c|c|c|c|c|}
\hline Residência & Número & $\begin{array}{c}\text { Origem na } \\
\text { própria } \\
\text { capitania }\end{array}$ & $\mathbf{0}$ & $\begin{array}{c}\text { Origem } \\
\text { reinol }\end{array}$ & $\mathbf{\%}$ & $\begin{array}{c}\text { Origem em } \\
\text { outras } \\
\text { capitanias }\end{array}$ & $\mathbf{\%}$ \\
\hline Pernambuco & 51 & 41 & 80,3 & 5 & 9,8 & 5 & 9,8 \\
\hline Bahia & 45 & 39 & 86,6 & 3 & 6,6 & 3 & 6,6 \\
\hline Rio de Janeiro & 37 & 20 & 54 & 13 & 35,1 & 3 & 10,8 \\
\hline Minas Gerais & 23 & 2 & 8,7 & 21 & 91,3 & 0 & 0 \\
\hline Pará & 12 & 5 & 41,6 & 5 & 41,6 & 2 & 16,6 \\
\hline São Paulo & 11 & 4 & 36,3 & 2 & 18,1 & 5 & 45,4 \\
\hline Maranhão & 7 & 2 & 28,5 & 3 & 42,8 & 2 & 28,5 \\
\hline Paraíba & 2 & 1 & 50 & 1 & 50 & 0 & 0 \\
\hline $\begin{array}{c}\text { Colônia do } \\
\text { Sacramento }\end{array}$ & 2 & 1 & 50 & 1 & 50 & 0 & 0 \\
\hline Espírito Santo & 2 & 1 & 50 & 1 & 50 & 0 & 0 \\
\hline Goiás & 2 & 0 & 0 & 0 & 0 & 2 & 100 \\
\hline Ceará & 2 & 0 & 0 & 0 & 0 & 2 & 100 \\
\hline Rio Grande do & 1 & 0 & 0 & 0 & 0 & 1 & 100 \\
\hline Norte & $\mathbf{1 9 8}$ & $\mathbf{1 1 6}$ & $\mathbf{5 8 , 5}$ & $\mathbf{5 5}$ & $\mathbf{2 7 , 7}$ & $\mathbf{2 6}$ & $\mathbf{1 3 , 1}$ \\
\hline Total & & & & & & 0 \\
\hline
\end{tabular}

Fonte: ANTT, HSO.

Embora houvesse casais formados pelos dois costados naturais da colônia ou pelos dois lados reinóis, os ascendentes dos comissários do Brasil caracterizavam-se por outra dominância. Em geral, tinham o costado paterno predominantemente de origem reinol e o lado materno frequentemente formado por mulheres nascidas na colônia, mas filhas de reinóis em sua

\footnotetext{
9 Ver no mesmo sentido SOUZA, Grayce Mayre Bonfim. Para remédio das almas: comissários, qualificadores e notários da Inquisição portuguesa na Bahia colonial. Vitória da Conquista: Edições Uesb, 2014, p.167-168.
} 
maioria. Este comportamento traduz as estratégias de reprodução social que adotavam os setores intermédios e as elites locais em relação ao mercado matrimonial da América portuguesa. ${ }^{10}$ Era ainda mais evidente no que se refere aos comerciantes de origem reinícola (caso de boa parte dos pais dos comissários). ${ }^{11}$ De um modo geral eram homens jovens que saíam do reino solteiros e muitas vezes era no Brasil que contraíam matrimônio, com as filhas de outros reinóis já estabelecidos.

\section{Gráfico 1}

\section{Origens geográficas dos pais dos comissários do Brasil (com processos de habilitação)}

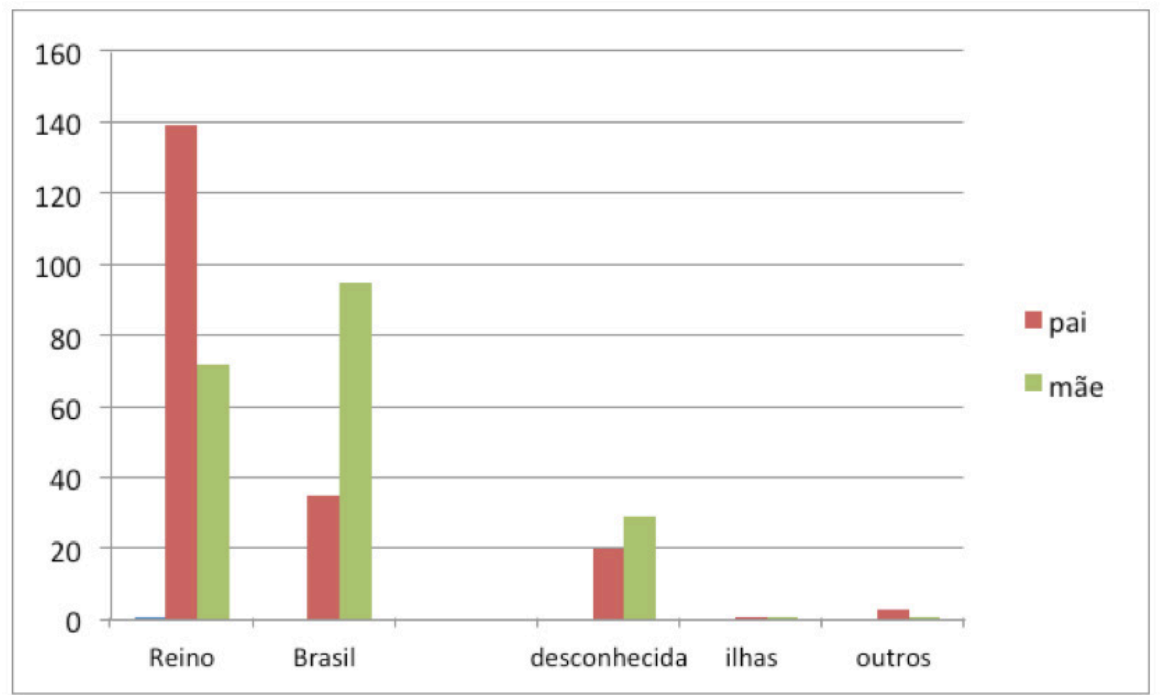

Fonte: ANTT, HSO.

\footnotetext{
${ }^{10} \mathrm{O}$ mesmo comportamento era registado nos vigários da vara. RODRIGUES, Aldair Carlos. Clergy, society, and power relations in colonial Brazil: On the vicar forane (vigário da vara), 1745-1800. e-journal of Portuguese History, Providence, 13, 1, jun 2015, p. 54.

${ }^{11}$ Por exemplo: FLORY, Rae $\mathcal{E}$ SMITH, David Grant. Bahian merchants and planters in the seventeenth and early eighteenth centuries. The Hispanic Historical American Review, 58 (4), 1978, p. 571-594. Ver sobretudo p. 576; KENNEDY, John Norman. Bahian elites, 1750-1822. The Hispanic Historical American Review, 53 (4), 1973, p. 415-439. No caso de São Paulo, Maria Aparecida de Menezes Borrego verificou que as esposas escolhidas pelos comerciantes de sua amostra (quase todos reinóis) "eram naturais da terra, em geral, nascidas na própria cidade e nas vilas vizinhas", cerca de 60\% delas eram aparentadas com agentes mercantis. BORREGO, Maria Aparecida de Menezes. A teia mercantil. Negócios e poderes em São Paulo colonial (1711-1765). São Paulo: Alameda, 2010, p. 240-241.
} 
Nas ilhas do Atlântico norte português, o quadro era diferente (ver tabela 3). A maioria dos comissários nascera no arquipélago respectivo, bem como os seus pais e avós. Assim, no espaço insular, esta observação aproximava-se mais da registada nas capitanias mais antigas do Brasil, como era o caso da Bahia.

\section{Tabela 3}

Comissários da Ilhas: origens dos pais e das mães

\begin{tabular}{|l|c|c|c|c|c|c|}
\cline { 2 - 7 } \multicolumn{1}{c|}{} & \multicolumn{3}{c|}{ Madeira } & \multicolumn{3}{c|}{ Açores } \\
\cline { 2 - 7 } & Comissário & Pai & Mãe & Comissário & Pai & Mãe \\
\hline Naturais & 23 & 14 & 17 & 15 & 12 & 12 \\
\hline Não naturais & 5 & 7 & 4 & 1 & 1 & 1 \\
\hline Não se sabe & 0 & 7 & 7 & 1 & 4 & 4 \\
\hline
\end{tabular}

Fonte: ANTT, HSO. A maioria dos "não se sabe" equivale a processos classificados como em "mau estado" na Torre do Tombo.

Entre os comissários do Brasil, de 198 pais cuja naturalidade é conhecida, 139 eram reinóis - na sua maioria do Minho (78) ${ }^{12}$-, 35 eram naturais da colônia, um era das ilhas, um de Angola e três tinham nascido no estrangeiro; para 20 não foi possível saber a naturalidade. No caso das mães, a tendência era a inversa: predominavam as mulheres nascidas no território americano - 95. As mães reinóis somavam 72 pessoas. ${ }^{13}$ Além dessas, uma era das ilhas e outra de Angola. Em 29 casos, não foi possível identificar o local de nascimento. Mesmo na Madeira, era maior o número de mães ali nascidas do que o número de pais.

Quanto aos avôs paternos, no Brasil, 133 nasceram no reino e apenas 11 foram dados à luz no espaço colonial; para 50 não se identificou o local de nascimento. Já entre suas consortes, 115 eram reinóis, 19 do Brasil, uma das ilhas, três estrangeiras e, para 60, não se dispõe desse tipo de informação. No que tange aos avôs maternos, foram encontrados os seguintes dados: 113 varões reinóis, 28 originários do Brasil, quatro das ilhas; para 54 não se loca-

\footnotetext{
${ }^{12}$ Minho: 78; Estremadura: 23; Beira: 18; Trás-os-Montes: 9; Alentejo: 3; sem especificação: 8.

${ }^{13}$ Minho: 34; Estremadura: 14; Beira: 14; Trás-os-Montes: 3; Alentejo: 2; sem especificação: 5.
} 
lizou esta informação. Em relação às esposas, 79 eram do Brasil, 73 do reino, uma das ilhas, uma de Angola e para 45 delas faltam dados.

O lado materno era sempre o que tinha mais raízes no espaço extra-europeu, tanto no caso do Brasil de Setecentos como para os restantes territórios estudados. Mesmo assim, muitos dos reinóis que regressavam ao reino faziam-no solteiros.

No vasto território da América portuguesa, a predominância dos naturais da colônia identificada aqui no âmbito das estruturas eclesiásticas (forneceu pelo menos 58\% da rede de comissários da Inquisição) teve correspondência no plano da burocracia da Justiça régia, como demonstrou o trabalho de Nuno Camarinhas. ${ }^{14}$ Os magistrados nascidos no Brasil foram penetrando intensamente no crescente aparelho judicial, sobretudo nas magistraturas inferiores (juízes de fora, ouvidores etc.), a partir das primeiras décadas do século XVIII. No plano mais elevado, porém, o Tribunal da Relação da Bahia, como demonstrou Schwartz, ${ }_{1}^{15}$ e o Tribunal da Relação do Rio de Janeiro, estudado por Wehling, ${ }^{16}$ permaneceram bastante fechados aos naturais do Brasil.

Em síntese, na medida em que o processo de ocupação avançava - liderado pela diversificação da pauta de exportação (com destaque para a mineração), por uma maior integração regional e pelo fortalecimento do setor mercantil dos principais portos $\operatorname{costeiros}^{17}$-, houve um significativo investimento nas estruturas administrativas (civil e eclesiástica) por parte das oligarquias locais e dos setores médios, por meio de seus rebentos. No caso das capitanias açucareiras, o fenômeno foi mais acentuado. Nos arquipélagos da Madeira e Açores (aqui sobretudo nas ilhas principais), a tendência foi semelhante pelo menos no que respeitava à Igreja.

\footnotetext{
${ }^{14}$ CAMARINHAS, Nuno. Juízes e administração da Justiça no Antigo Regime. Portugal e o Império colonial, séculos XVII e XVIII. Lisboa: Fundação Calouste Gulbenkian, FCT, 2011, p. 123-124.

${ }^{15}$ Como foi demonstrado por Schwartz, as elites locais não conseguiram dominar essa instituição. Cf. SCHWARTZ, Stuart. Burocracia e sociedade no Brasil colonial. São Paulo: Perspectiva, 1979, p. 148, p.311-325.

${ }^{16}$ No caso do Rio de Janeiro (1751-1808), embora a importância dos naturais do Brasil fosse crescente, os reinóis ainda dominavam o Tribunal da Relação: eram 70,3\% dos desembargadores. Cf.: WEHLING, Arno \& WEHLING, Maria José. Direito e Justiça no Brasil colonial: o Tribunal da Relação do Rio de Janeiro (1751-1808). Rio de Janeiro: Renovar, 2004, p. 268-269.

${ }^{17}$ BETHENCOURT, Francisco \& CHAUDHRI, Kirti (dir.). História da expansão portuguesa, vol. 3. Lisboa: Temas e Autores e Debates, Círculo dos Leitores, 1998; BOXER, Charles R. A Idade de Ouro do Brasil: dores do crescimento de uma sociedade colonial. São Paulo: Cia Editora Nacional, 1979.
} 


\section{b. Ocupação dos progenitores e estatuto social}

O perfil ocupacional dos pais dos comissários moradores no Brasil revela que eles eram oriundos de um espectro social aparentemente pouco homogêneo, embora com algumas tendências bem claras (tabela 4). Foi possível identificar a ocupação dos progenitores de 149 agentes. A atividade de maior destaque era a mercantil, ${ }^{18}$ seguida pelas lavouras e, depois, pelos ofícios mecânicos e postos militares. Um grupo menor de pessoas acumulava mais de uma atividade ocupacional. Destas últimas, 14 se dedicavam às lavouras e também a outras ocupações. Isso porque esse setor atraía tanto os comerciantes como os oficiais mecânicos e os militares ou postos de ordenança. Dado o grande peso que os escravos e os bens de raiz tinham na demarcação das hierarquias sociais no contexto em análise, tal coexistência era frequente. O comércio foi elemento de combinação em 11 casos, sendo associado a lavouras, "fazendas", ofícios mecânicos, casas de aluguel e administração. Os ofícios mecânicos aparecem em oito casos de acúmulo de ocupação e os ofícios militares, em cinco. Na maioria das vezes, não foi possível definir qual a atividade que mais atraiu os indivíduos do grupo. Por isso mesmo, manteve-se esta entrada conjunta.

\footnotetext{
${ }^{18}$ O pico de habilitação de filhos de comerciantes ocorreu entre 1761-1790, quando foram habilitados dez em cada decênio desse intervalo. Nesse mesmo período, os filhos de lavradores eram: oito, dois e cinco, sucessivamente, para cada década do intervalo considerado. Nos demais períodos e nas outras ocupações, não houve variações dignas de nota.
} 


\section{Tabela 4}

Ocupação dos pais dos comissários

\begin{tabular}{|c|c|c|c|c|c|c|}
\hline \multirow[b]{2}{*}{ Ocupação - Setor } & \multicolumn{2}{|c|}{ Brasil } & \multicolumn{2}{|c|}{ Madeira } & \multicolumn{2}{|c|}{ Açores } \\
\hline & $\mathbf{N}^{\mathbf{o}}$ & $\begin{array}{c}0 \% \\
\text { (sobre } \\
\text { total) }\end{array}$ & $\mathbf{N}^{\mathbf{o}}$ & $\begin{array}{c}0 \% \\
\text { (sobre } \\
\text { total) }\end{array}$ & $\mathbf{N}^{\mathbf{o}}$ & $\begin{array}{c}0 \% \\
\text { (sobre } \\
\text { total) }\end{array}$ \\
\hline Comércio & 44 & 22 & 4 & 14 & 0 & 0 \\
\hline Lavouras & 31 & 16 & 3 & 11 & 2 & 12 \\
\hline Ofícios mecânicos - artesãos & 21 & 11 & 5 & 18 & 1 & 6 \\
\hline Militar /ordenanças & 11 & 6 & 4 & 14 & 3 & 18 \\
\hline Administração/Justiça & 6 & 3 & 2 & 7 & 1 & 6 \\
\hline Vive de sua fazenda & 5 & 3 & 0 & 0 & 1 & 6 \\
\hline Medicina & 2 & 1 & 0 & 0 & 1 & 6 \\
\hline Mestre de gramática & 1 & 1 & 0 & 0 & 0 & 0 \\
\hline Ocupações combinadas & 28 & 14 & 0 & 0 & 2 & 12 \\
\hline Sem ocupação - fidalgo/nobre & 0 & 0 & 1 & 4 & 1 & 6 \\
\hline Sem identificação & 49 & 25 & 9 & 32 & 5 & 29 \\
\hline Total & 198 & 100 & 28 & 100 & 17 & 100 \\
\hline
\end{tabular}

Fonte: ANTT, HSO.

Nos arquipélagos atlânticos considerados faltam dados para muitos pais. No entanto, na Madeira, os pais artesãos contavam-se entre os mais numerosos, imediatamente seguidos dos ligados às ordenanças e ao comércio. Pouco depois vinham os que se ocupavam no cultivo dos campos. Nos Açores, eram as ordenanças que mais se destacavam. Os pais que acumulavam ocupações apresentavam uma vertente de comércio e agricultura.

Na realidade, nestas sociedades atlânticas, o mais notório era o lugar diminuto da nobreza ou da fidalguia fora das cidades principais de cada território. Comércio, agricultura, defesa e algum artesanato marcavam um forte quadrilátero da vida local e as possibilidades de singrar, dando ordens de missa a pelo menos um descendente direto. Quando eram bem sucedidos, os grupos intermédios forjavam-se neste pano de fundo. Alguma riqueza e aproveitamento de oportunidades conjunturais permitiam um afastamento crescente das camadas populares, sem que houvesse propriamente integração na nobreza. Colocar um filho no clero era uma via fulcral e muitas vezes fácil para permitir afastamento distintivo em relação ao comum, até porque 
os montantes dos patrimônios exigidos não eram elevados e eram múltiplas e plásticas as formas de alcançar esse dote. ${ }^{19}$

Os dados expostos não são, todavia, suficientes para caracterizar os comissários do Santo Ofício. Entre estes havia uma clivagem muito clara entre os reinóis e os que eram naturais do espaço atlântico. No caso do Brasil, entre os padres de origem metropolitana sobressaíam os clérigos filhos de lavradores. Já entre os naturais da terra - a esmagadora maioria da rede havia um forte predomínio dos filhos de comerciantes. Entre estes últimos, no entanto, os pais eram, em boa parte, reinóis que migraram para a América. A genealogia dos filhos bem sucedidos não tinha, assim, raízes de muitas gerações no Novo Mundo.

Sobre os comissários de origem americana, em números, as atividades mercantis (setor mais saliente) ocupavam 39 pais, distribuídos por variados ramos de atuação, entre o atacado e o varejo. Isto contando aqueles que apenas se dedicavam a esta ocupação. Se for incluído nesse cômputo os que estavam ligados ao comércio e também a outras ocupações, o número aumenta para 48. Nesses casos de atividades acumuladas, o comércio aparecia aliado a fazendas, lavouras, cargos administrativos e postos militares.

Entre todos os 59 comissários de origem reinol, conhecemos a ocupação dos pais de 55 eclesiásticos. Predominavam, de longe, aqueles que eram filhos de lavradores: 24 casos, dos quais 18 eram apenas lavradores, e, em seis casos, esta ocupação aparecia combinada com ofícios mecânicos. Em segundo lugar, estavam os artesãos (sapateiros, pedreiros, ferreiros e alfaiates), abrangendo 21 progenitores. Destes, 13 viviam apenas dessa atividade e, nos demais casos, ela era exercida conjuntamente com outras, quatro delas já mencionadas porque exercidas simultaneamente com as lavouras. Apenas sete comissários oriundos do reino eram filhos de comerciantes, dois dos quais se dedicavam a outras ocupações. No mais, cinco viviam de suas fazendas, um estava ligado à administração local, dois eram militares (um dos

\footnotetext{
${ }_{19}$ OLIVAL, Fernanda $\mathcal{E}$ MONTEIRO, Nuno Gonçalo. Movilidad social en las carreras eclesiásticas en Portugal (1500-1820). In: JIMÉNEZ, F. Chacón \& MONTEIRO, Nuno Gonçalo (coord.). Poder y movilidad social: cortesanos, religiosos y oligarquías en la península Ibérica (siglos XV-XIX). Madri: CSIC, 2006, p. 105-106. Na ilha de S. Miguel, nos Açores, 63,3\% dos ordinandos setecentistas tinham patrimônios acima do valor mínimo estabelecido pela respectiva diocese e $71 \%$ dos outorgantes de dotes declarara que o mesmo só era válido em vida do presbítero ou até o padre conseguir benefício, "pelo qual receba 'pão del rei'". COSTA, Susana Goulart. Viver e morrer religiosamente: a ilha de S. Miguel, século XVIII. Ponta Delgada: Instituto Cultural, 2007, p. 139-145.
} 
quais era também lavrador e já foi considerado), um era mestre de Gramática e outro era filho de "pais ricos".

Os comissários nascidos no reino saíram predominantemente de setores sociais baixos e, no máximo, intermédios. Talvez por isso demandaram o império ultramarino. Entre os pais, apenas em 14 casos havia menção a algum estatuto social, sobretudo de âmbito local. Cinco tinham postos nas ordenanças e forças militares, como capitão-mor ou sargento-mor; quatro progenitores eram familiares do Santo Ofício, e um era cavaleiro da Ordem de Cristo. Raros eram os que ocupavam os "cargos da res publica" ou faziam parte dos "principais da terra", que viviam "à lei da nobreza", como um descrito através da expressão "lavrador honrado". Somente um era "fidalgo de sua majestade". Ou seja, poucos foram os agentes nascidos em Portugal descendentes das elites locais. Em geral quem saía para o ultramar estava mal posicionado na escala social. Este comportamento mantinha-se pelo menos desde o século XVI.

Se entre os comissários reinóis havia uma preponderância das origens sociais mais baixas, com pouca incidência de estatuto social relevante entre os progenitores, no lado atlântico, a situação se invertia. Apesar da heterogeneidade social, percebemos que boa parte dos agentes originários do Brasil era composta por rebentos das elites locais, sobretudo de extração mercantil. Em um pouco mais da metade dos casos (72, em um total de 139), eles eram filhos de pais portadores de algum estatuto social, de eficácia maiormente local. Um percentual relevante tinha familiatura da Inquisição e/ou postos de capitão, capitão-mor, sargento-mor, dentre outros. De modo geral, os progenitores comerciantes foram os que mais obtiveram lugares e insígnias que ofereciam distinção social.

Em resumo, considerando a naturalidade, a ocupação e o estatuto social dos pais dos comissários, constatamos que entre os nascidos na América portuguesa havia uma presença assinalável daqueles oriundos das elites locais, sobretudo nas capitanias mais antigas. A entrada para as estruturas de poder da Igreja era uma estratégia de confirmação da posição alcançada por esses agentes e suas famílias.

Nos arquipélagos estudados, regista-se uma observação semelhante. Na Madeira, conhece-se a naturalidade de todos os comissários deste período. É entre alguns dos cinco que não eram oriundos da ilha que se assinalaram várias das ocupações mais baixas na escala social. O pai de Bernardo 
Rodrigues Nogueira contratava com lãs; ${ }^{20}$ o de Antônio Mendes de Almeida primeiro fora sapateiro, depois criado de escada acima e a mãe era padeira; ${ }^{21}$ o de José Martins de Faria não passara de oficial de carpinteiro. ${ }^{22}$ No caso dos Açores, o pai do comissário que garantidamente nascera fora do arquipélago (o padre Manuel dos Santos Rolim) era pasteleiro e o avô paterno vivera de tratar e conduzir porcos ao Alentejo, e os maternos, de seu trabalho e searas. ${ }^{23}$ Os comissários oriundos da terra, com uma outra exceção, situavam-se num patamar acima. Estavam menos mergulhados nas camadas populares; pertenciam claramente aos grupos intermédios e, nalguns casos, à nobreza.

Na verdade, globalmente neste universo, para os comissários nascidos no reino a carreira eclesiástica cruzada com a do Santo Ofício foi mais uma estratégia de mobilidade social ascendente do que para os oriundos dos espaços ultramarinos considerados.

O fato de a elite colonial ter ficado alijada da nobreza titulada ${ }^{24}$ e longe do centro político tornava todos os cargos, privilégios e insígnias com algum capital simbólico extremamente atrativos e disputados para esse setor. Os grupos intermédios e a nobreza local constituíam espaços sociais ávidos por distinção e reconhecimento. As habilitações para ordens menores e sacras, bem como as do Santo Ofício - muito em função da entrada dos estatutos de limpeza de sangue nos códigos sociais a partir de meados do século XVI e inícios do XVII ${ }^{25}$ - faziam parte desse jogo. Elas integravam um conjunto mais amplo de estratégias que incluía: a obtenção de escravos e bens de raiz (sobretudo terras), a ocupação dos cargos da governança local (ou "cargos da res publica"), a entrada nas irmandades segregacionistas (ofereciam mais prestígio), a luta por hábitos das ordens militares, sobretudo da Ordem de Cristo, e investimento no estilo de vida, procurando "tratar-se à lei da nobreza". Os elementos que compunham tal espiral de símbolos de distinção não possuíam os mesmos valores e eficácias sociais e simbólicas das observadas no Portugal metropolitano. O lugar deles na escala do Brasil (cuja sociedade

${ }^{20}$ ANTT, HSO. Bernardo, maço 5, doc. 76, f. não numerado.

${ }^{21}$ ANTT, HSO. António, maço 91, doc. 1708, f. 7, 8v.

22 ANTT, HSO. José, maço 50, doc. 803, f. 29v.

${ }^{25}$ ANTT, HSO. Manuel, maço 154, doc. 1576, f. 14v, 23v.

${ }^{24}$ BETHENCOURT, Francisco \& SÁ, Isabel Guimarães. As câmaras e as misericórdias. In: História da expansão portuguesa..., op. cit., p. 270-291, p. 275.

${ }^{25}$ OLIVAL, Fernanda. Rigor e interesses: os estatutos de limpeza de sangue em Portugal. Cadernos de Estudos Sefarditas, no 4, 2004, p. 151-182; FIGUEIRÔA-RÊGO, João. A honra alheia por um fio. Os estatutos de limpeza de sangue nos espaços de expressão ibérica (séculos XVI- XVIII). Lisboa: Fundação Calouste Gulbenkian, FCT, 2011. 
era marcada pela miscigenação e pelo escravismo) ${ }^{26}$ e das ilhas era muito elevado, mas era baixo se comparado aos padrões de distinção da metrópole. No espaço da península Ibérica estava no topo uma nobreza titulada de tradição secular e a sociedade era - comparativamente - menos fluída e de mobilidade ascendente menos intensa e menos acelerada. ${ }^{27}$

Mesmo assim, o vasto Brasil não era todo uniforme, como foi referido. As configurações tinham variantes regionais com frequência significativas, decorrentes da decantação das elites nas dioceses do litoral, especialmente nas mais antigas e consolidadas.

\section{Naturais da terra / reinóis e instituições eclesiásticas}

\section{a) Primeiras aproximações}

Stuart Schwartz aponta o surgimento de rivalidades entre segmentos nascidos em Portugal e grupos nascidos no território americano no seu estudo acerca da emergência de uma identidade colonial no Brasil, a partir do século XVII e, sobretudo, do século XVIII. Ao lado das rusgas entre os dois grupos havia ao mesmo tempo acomodações, sobretudo por meio do mercado matrimonial, que tendiam a incorporar os varões reinóis. Na medida em que os patamares superiores da sociedade colonial passaram a ser compostos majoritariamente pela segunda e terceira gerações de imigrantes portugueses, as tensões tenderiam a se acentuar. As fricções ocorriam entre estes últimos e os reinóis adventícios, em particular nas disputas pelo acesso aos órgãos

\footnotetext{
${ }^{26}$ SCHWARTZ, Stuart. Segredos internos: engenhos, e escravos na sociedade colonial (1550- 1835). São Paulo: Companhia das Letras, 1988. Ver sobretudo o capítulo 9, p. 209-223.

${ }^{27}$ BETHENCOURT, Francisco \& SÁ, Isabel Guimarães. As câmaras e as misericórdias, op. cit., p. 270-291, p. 275. OLIVAL, Fernanda. Rigor e interesses: os estatutos de limpeza de sangue em Portugal, op. cit., $\mathrm{n}^{\circ}$ 4, 2004, p. 151-182; FIGUEIRÔA-RÊGO, João. A honra alheia por um fio, op. cit., 2011. SCHWARTZ, Stuart. Segredos internos, op. cit., 1988; MELLO, Evaldo Cabral de. O nome e o sangue: uma fraude genealógica no Pernambuco colonial. São Paulo: Companhia das Letras, 1989; RUSSEL-WOOD, A. J. Fidalgos e filantropos. A Santa Casa de Misericórdia da Bahia. Brasília: Ed. UNB, 1981; BLAJ, Ilana. A trama das tensões: o processo de mercantilização de São Paulo colonial (1681-1721). São Paulo: Humanitas; FFLCH/USP, 2002; SILVA, Maria Beatriz Nizza. Ser nobre na colônia. São Paulo: Editora da Unesp, 2004; SOUZA, Laura de Mello e. O sol e a sombra. Política e administração na América portuguesa do século XVIII. São Paulo: Companhia das Letras, 2006, cf. principalmente o cap. 4, p. 148-188; CUNHA, Mafalda Soares (org.). Do Brasil à metrópole: efeitos sociais (séculos XVII-XVIII). Separata da Revista Anais da Universidade de Évora, no 8 e 9, Évora, dezembro 1998/1999, p 47-72. SCHWARTZ, Stuart. Segredos internos..., op. cit., ver sobretudo o capítulo 9, p. 209-223.
} 
de poder. Segundo o autor, foi no espaço institucional das ordens religiosas que a clivagem reinóis/naturais da terra emergiu de forma mais estridente. ${ }^{28}$

Com efeito, entre os beneditinos, de 287 monges que faleceram no mosteiro da Bahia entre 1591 e 1815, somente 114 (38\%) haviam nascido na colônia. Tal quadro levou os membros da ordem chegados ao mundo no Brasil a expressar suas frustrações em carta escrita ao rei em 1738. Argumentavam que em 157 anos a ordem havia sido governada por 45 provinciais eleitos na América portuguesa, porém somente seis deles eram naturais da terra. ${ }^{29}$ No Rio de Janeiro, de acordo com Jorge Victor de Araújo, durante o século XVII, metade dos 48 noviços do mosteiro de São Bento era ali nascida. Para a centúria seguinte, de um total de 83 monges, o autor identificou a naturalidade de 75, dos quais 66\% haviam nascido na colônia. Quase sempre eram provenientes das "melhores famílias da terra". ${ }^{30}$ Apesar desta configuração, a câmara clamava ao rei, em 1722, "que os beneditinos não aceitam nascidos na terra senão com as cláusulas de que os seus pais contribuam com um donativo tão numeroso que chega a ser um bom dote de freira". ${ }^{31}$ Súplicas com este teor continuaram a seguir para Lisboa.

Quanto aos jesuítas, em 1688, o padre Antônio Vieira informava que de 33 provinciais e visitadores da ordem no Brasil desde 1549, apenas três eram nascidos no território colonial. No quadro geral, a província admitira 310 naturais da terra, enquanto que o número de reinóis ou naturais das ilhas atlânticas portuguesas perfazia um total de 538 ingressos. $^{32}$

Nos institutos franciscanos, as disputas entre a facção formada por "filhos de fora" e a sua contraparte formada por "filhos da terra" ganhava contornos claros ao longo do século XVIII, sobretudo na província do Rio de Janeiro (Imaculada Conceição, criada em 1657). Para arbitrar os conflitos, o papa Inocêncio XIII promulgou a Lei da Alternativa em 1718, que foi confirmada em 1720 (pela Bula da Alternativa) e regulada por provisão régia em 1721. As rivalidades, no entanto, continuaram. Ambos os lados mantiveram

\footnotetext{
${ }^{28}$ SCHWARTZ, Stuart. The formation of a colonial identity in Brazil, In: CANNY, N. \& PAGDEN, A. (ed.). Colonial identity in the Atlantic world, 1500-1800. Princeton: Princeton University Press, 1987, p. 41.

${ }^{29}$ Ibidem, p. 42.

${ }^{30}$ SOUZA, Jorge Victor de Araújo. Poder local entre ora et labora: a casa beneditina nas tramas do Rio de Janeiro seiscentista. Tempo, Revista do Departamento de História da UFF, v. 32, 2012, p. 69-94, p. 83. Do mesmo autor consultar SOUZA, Jorge Victor de Araújo. Para além do claustro: uma história social da inserção beneditina na América portuguesa, c. 1580 - c. 1690. Niterói: Eduff, 2014.

${ }^{31}$ AHU-RJ, caixa 13, doc. 134, 26 de novembro de 1722. Apud: SOUZA, Jorge Victor de Araújo. Poder local entre ora et labora..., op. cit., 2012, p. 83.

${ }^{32}$ Ibidem, p. 43-44.
} 
rev. hist. (São Paulo), n. 175, p. 25-67, jul.dez., 2016 http://dx.doi.org/10.11606/issn.2316-9141.rh.2016.124067
Aldair Carlos Rodrigues \& Fernanda Olival Reinóis versus naturais nas disputas pelos lugares eclesiásticos do Atlântico português: aspectos sociais e políticos (século XVIII)

procuradores em Portugal para representar seus interesses, sempre em tensão. ${ }^{33}$ No ano de 1779, quando a Lei da Alternativa foi quebrada, segundo Schwartz, os naturais do Brasil predominavam na província, com 173 membros, ao passo que os reinóis perfaziam $105 .{ }^{34}$

Facções também se digladiavam durante o Setecentos no convento dos carmelitas do Rio de Janeiro. Tudo redundou, durante a década de 1780, na intervenção do vice-rei Luís de Vasconcelos e Sousa e do bispo diocesano, d. José Joaquim Justiniano Mascarenhas Castelo Branco, para aplacar as rusgas no contexto regalista da época, conforme foi bem analisado por Leandro Lima. ${ }^{35}$ As parcialidades no interior da ordem eram configuradas em torno, por um lado, dos "filhos do Rio" e, por outro, dos "filhos de fora". Dados de 1783 citados pelo autor indicam que apenas seis membros da província eram reinóis. Neste caso, comparativamente às zonas anteriormente mencionadas, sobressaía uma identidade mais acentuadamente regional nas disputas. Os frades naturais da capitania do Rio predominavam, com 50\% dos frades (71 indivíduos). ${ }^{36}$ Este quadro era diferente do que se passava entre os carmelitas descalços de Olinda, ordem fundada em 1686, que nem chegava a admitir nascidos no Brasil. ${ }^{37}$

Nos Açores, os dados disponíveis apontam para uma maioria clara de açoreanos nos conventos masculinos micaelenses setecentistas, feita talvez exceção às casas dos jesuítas. ${ }^{38} \mathrm{~A}$ bibliografia até agora publicada não reporta o tipo de contendas que foram traçadas para o Brasil. Faz notar, contudo, em torno das agremiações femininas, a importância da ligação das parentelas locais a determinados conventos, bem como a relevância de dispor dos cargos diretivos eleitos. ${ }^{39}$ A sua influência ia muito além dos claustros e tinha um impacto forte na esfera secular.

\footnotetext{
33 SILVA, Leandro Ferreira da. Regalismo no Brasil colonial: a Coroa portuguesa e a província de Nossa Senhora do Carmo do Rio de Janeiro (1750-1808). Dissertação de mestrado, FFLCH-USP, São Paulo, 2013, p. 78.

${ }^{34}$ SCHWARTZ, Stuart. The formation of a colonial identity..., op. cit., p. 43.

${ }^{35}$ Cf. SILVA, Leandro Ferreira da. Regalismo no Brasil colonial, op. cit., 2013. Ver sobretudo p. 77-88.

${ }^{36}$ Os restantes: 24,6\% (35 indivíduos) eram naturais da capitania de São Paulo; 7\% (10 indivíduos) de Minas Gerais; 8,5\% (12 indivíduos) do Espírito Santo; 4,2\% (6 indivíduos) de Portugal; 2,1\% (3 indivíduos) das ilhas; 0,7\% (1 indivíduo) da Colônia de Sacramento; e para 2,8\% (4 indivíduos) o autor não localizou suas origens. Cf. SILVA, Leandro Ferreira da. Regalismo no Brasil colonial.., op. cit., p. 232.

${ }^{37}$ Ibidem, p. 44.

${ }^{38}$ RODRIGUES, José Damião. São Miguel no século XVIII: casa, elites e poder, vol. I. Ponta Delgada: Instituto Cultural de Ponta Delgada, 2003, p. 468-471.

${ }^{39}$ Ibidem, p. 491-498; RODRIGUES, José Damião. Poder municipal e oligarquias urbanas: Ponta Delgada no século XVII. Ponta Delgada: Instituto Cultural de Ponta Delgada, 1994, p. 162-174.
} 
Sob vários pontos de vista, era importante para os locais poder controlar estes lugares que ofereciam vantagens sociais. Tal domínio e disputa estendiam-se a outros postos. Traduziam a afirmação das periferias coloniais face ao centro e, para além das implicações sociais, assumiam uma conotação política notória. Veja-se o caso dos cabidos catedralícios, um aparato institucional que, à escala regional, tendeu a acolher a elite do clero secular.

\section{b) Cabidos}

Nos cabidos, as disputas entre reinóis e naturais da terra pelos lugares de poder apareceram de maneira contundente sobretudo a partir da segunda metade do século XVII. Estas tensões foram adquirindo forte significado político, inclusive com a participação ativa das câmaras municipais.

Em termos comparativos, as catedrais do território brasileiro eram constituídas por um número de prebendas inferior ao dos cabidos do reino. Enquanto a Sé de Coimbra, por exemplo, em 1588, estava dotada com 32 prebendas $^{40}$ e Évora com 26, de finais do século XVI até pelo menos ao começo do século XVIII, ${ }^{41}$ o corpo capitular da catedral do Rio de Janeiro foi instituído em 1685 com cinco dignidades (deão, chantre, tesoureiro-mor, mestre-escola e arcediago), seis conezias de prebenda inteira e duas de meia prebenda. Em 1735, d. João V autorizou a criação de mais cadeiras, sendo instituídas três conezias qualificadas - doutoral, magistral e penitenciária e mais duas de meia prebenda. Nesse mesmo ano, o número de capelães foi dobrado e posteriormente, em 1750, essa cifra foi aumentada outra vez, com mais três capelanias, completando 12. O benefício curado da Sé foi elevado à categoria de conezia paroquial em $1758 .{ }^{42}$

A diocese de Mariana foi criada em 1745 e o alvará régio que autorizava a instalação do cabido catedralício é datado de 2 de maio de 1747. Seu corpo capitular era composto por 14 prebendas: quatro dignidades (arcediago, arcipreste, chantre e tesoureiro-mor), dez conezias (sendo três delas de ofí-

\footnotetext{
${ }^{40}$ SILVA, Hugo Ribeiro da. O cabido da Sé de Coimbra. Os homens e a instituição (1620-1670). Lisboa: Imprensa do Instituto de Ciências Sociais da Universidade de Lisboa, 2011, p. 28.

${ }^{41}$ DÍAZ RODRÍGUEZ, Antonio J. \& LÓPEZ-SALAZAR CODES, Ana Isabel. El cabildo catedralicio de Évora en la Edad Moderna (1547-1801). Historia y Genealogía, nº 4, 2014, p. 42-43, 56-57.

${ }^{42}$ Todas essas informações em ARAÚJO, José de Souza Azevedo Pizarro. Memórias históricas do Rio de Janeiro, vol. 6. Rio de Janeiro: Imprensa Nacional, 1946, p. 7-16, 67-176; AMCM-RJ. Livro de Tombo (1722-1840), caixa 95, unidade 1.
} 
rev. hist. (São Paulo), n. 175, p. 25-67, jul.dez., 2016 http://dx.doi.org/10.11606/issn.2316-9141.rh.2016.124067
Aldair Carlos Rodrigues \& Fernanda Olival

Reinóis versus naturais nas disputas pelos lugares eclesiásticos do Atlântico português: aspectos sociais e políticos (século XVIII)

cio: doutoral, magistral e penitenciária), além de um conjunto de auxiliares, como sacristães, moços do coro, mestres de capela, porteiro e organista. ${ }^{43}$

Diferentemente do cabido fluminense, do baiano e dos metropolitanos, em Mariana não havia a dignidade de deão, que era sempre a primeira na hierarquia das cadeiras capitulares. Com efeito, tal como em São Paulo, o arcediago equivalia à primeira dignidade da instituição. Por isso mesmo, a apresentação direta das vacaturas deste tipo de cadeira pertencia à Coroa (ao rei na qualidade de mestre, pois detinha a apresentação da primeira dignidade em todas as catedrais do ultramar, independentemente da designação).

O cabido de São Paulo possuía a mesma configuração do marianense. A diferença residia apenas no valor das côngruas, em virtude do custo de vida nessa cidade ser menor do que na zona mineradora. ${ }^{4}$

Nos cabidos insulares, a dignidade primeira era sempre o deão. Comparando com o Brasil, o cabido do Funchal ou o de Angra eram grandes. O primeiro em 1735 era constituído por cinco dignidades (deão, arcediago, chantre, tesoureiro-mor e mestre-escola), 12 cônegos (sendo um magistral e outro penitenciário), quatro meios cônegos, 10 capelães, seis moços de coro, dois curas, além de vários outros elementos menores. ${ }^{45}$ Em Angra, a grande diferença em relação a Madeira era a existência de seis cônegos de meia prebenda. ${ }^{46}$

A instituição capitular exercia uma função basilar na carreira eclesiástica e na administração diocesana, na medida em que fornecia o elemento humano para os diversos postos do alto oficialato episcopal. Os benefícios do cabido, por oferecerem uma carreira, garantirem rendimento e serem vitalícios, vertebravam os percursos dos clérigos; permitiam-lhes que cumulativamente exercessem uma série de outras funções e cargos amovíveis, dependentes da graça do bispo. Por exemplo, o bispado do Rio de Janeiro teve treze vigários-gerais (a função mais elevada da Justiça eclesiástica) no decorrer do século XVIII e todos eles foram recrutados no cabido. ${ }^{47} \mathrm{O}$ bis-

\footnotetext{
43 Todas essas informações em BOSCHI, Caio (fixação dos textos, organização e estudo introdutório). O cabido da Sé de Mariana (1745-1820). Documentos básicos. Belo Horizonte: Fundação João Pinheiro, Editora PUC-MG, 2011, p. 14-15. (Coleção Mineiriana).

${ }^{44}$ CAMARGO, monsenhor Paulo Florêncio da Silveira. A Igreja na história de São Paulo (1745-1771), vol. 4. São Paulo: Instituto Paulista de História e Arte Religiosa, 1953, p. 9-11.

45 ASV. Congr. Concilio, Rel. Dioec., nº 352, f. 187; NORONHA, Henrique Henriques de. Memórias seculares e eclesiásticas para a composição da história da diocese do Funchal na ilha da Madeira. Funchal: Secretaria Regional do Turismo e Cultura; Centro de Estudos de História do Atlântico, 1996, p. 148-152.

${ }^{46}$ COSTA, Susana Goulart, op. cit., p. 68-69.

47 ARAÚJO, monsenhor José de Souza de Azevedo Pizarro. Memórias históricas do Rio de Janeiro, vol. 5; SANTOS, Antônio Alves Ferreira dos. A Archidiocese de São Sebastião do Rio de Janeiro: subsídios para a
} 
pado de Mariana seguiu tendência idêntica, pois todos os seus 10 vigáriosgerais eram membros do clero catedralício. ${ }^{48}$ Nas ilhas atlânticas, especialmente na Madeira, a situação seria semelhante.

Os postos prebendados (canonicatos e dignidades) dos cabidos do Brasil e das ilhas pertenciam ao padroado da Ordem de Cristo. Após a anexação dos três mestrados das ordens militares (Cristo, Santiago e Avis) à Coroa em 1551, o monarca passou a ser o mestre e perpétuo administrador dessas milícias (antes só tutelava vitaliciamente a Ordem de Cristo). A partir dessa fase, a gestão da quase totalidade dos recursos das ordens, inclusive o provimento dos benefícios eclesiásticos, passou a ser feito pela Mesa de Consciência e Ordens, onde quase sempre o rei-mestre tinha a última palavra. ${ }^{49}$

No entanto, no ultramar, após a criação das primeiras dioceses no século XVI, rapidamente os monarcas, no seu papel de perpétuos administradores da Ordem de Cristo, passaram a delegar aos prelados a nomeação dos clérigos dos respectivos bispados. O mesmo aconteceu com as conezias e dignidades do cabido, exceto o lugar de deão ou a primeira dignidade. Mesmo assim, no século XVIII, e até antes, uma pequena parte dos provimentos fizeramse por decretos, mediante súplica à Mesa, sem concurso ou interferência do bispo no processo. Normalmente, as vacaturas de cônegos e dignidades que ocorriam durante o período de sede vacante tinham concursos efetuados em Lisboa, pela Mesa da Consciência e Ordens. Nas mesmas circunstâncias, os cabidos faziam os concursos para as vigararias e benefícios curados, embora viessem a Lisboa para o apuramento final. No entanto, em sede plena ou vacante, caso a Mesa julgasse que os aprovados nos concursos eram pouco habilitados para os cargos, poderia abrir edital para a mesma vaga em Lisboa,

história eclesiástica do Rio de Janeiro, capital do Brasil. Rio de Janeiro: Tipographia Leuzinger, 1914; ANTT, MCO. Padroados do Brasil, Bispado do Rio de Janeiro, maço 15 e maço 16; ANTT, HSO. António, maço 125, doc. 2119; Gaspar, maço 8, doc. 171; José, maço 43, doc. 685; Manuel, maço 98, doc. 1820.

48 AEAM. Livros de provisões; TRINDADE, cônego Raimundo. A Arquidiocese de Mariana, op. cit., p. 365-367; ANTT, MCO. Padroados do Brasil, Bispado; ANTT, HSO. Geraldo, maço 1, doc. 11; Inácio, maço 6, doc. 95; Manuel, maço 170, doc. 1797; Teodoro, maço 1, doc. 18.

${ }^{49}$ Consolidado em 1551, o padroado ultramarino permitiu à Coroa de Portugal exercer jurisdição espiritual e temporal sobre as conquistas, cumprindo assim um papel importante na legitimação da expansão marítima. O direito de padroado envolvia uma série de privilégios e deveres por parte da monarquia lusitana. Os reis gozavam da prerrogativa de nomear os bispos das dioceses coloniais à Santa Sé, decidir sobre os provimentos dos benefícios (cargos vitalícios pagos pela Coroa) das catedrais e das igrejas paroquiais e deter o controle sobre a arrecadação dos dízimos, na qualidade de mestre das ordens militares. Em contrapartida, o monarca obrigava-se a promover a missionação e expansão da fé católica, além da instalação e manutenção das estruturas eclesiásticas. 
depois era realizada consulta ponderando os resultados das duas oposições para efetuar o provimento. ${ }^{50}$ Unicamente os curatos anuais e os ofícios estavam dispensados desta última formalidade, na falta do bispo ou arcebispo. ${ }^{51}$

Desta forma, o modelo de provimento dos lugares do cabido da América portuguesa (assim como no caso dos benefícios paroquiais deste território) e de todo o Atlântico incidia de forma homogênea em todas as catedrais, pois todas as prebendas pertenciam ao padroado da Ordem de Cristo. Tratava-se de uma configuração muito diferente da observada no reino, onde não havia um quadro único e os conflitos eram frequentes por esse fato em particular. Normalmente, a apresentação dos candidatos às vacaturas reinóis ocorridas nos meses apostólicos pertencia à Santa Sé (janeiro, abril, maio, julho, agosto, outubro e novembro), nos demais meses (março, junho, setembro e dezembro), o direito de apresentação era dividido entre o bispo e o próprio cabido. No decurso da época moderna, conforme Hugo Ribeiro da Silva, o rei foi aumentando sua capacidade de intervenção na escolha dos cônegos e dignidades no momento de criação de novas dioceses no território metropolitano, ao mesmo tempo em que os prelados, no contexto tridentino, também faziam crescer sua influência no processo. A partir do século XVI, por privilégio régio, a Universidade de Coimbra tornou-se mais um vetor de influência nos provimentos. Passou ela a organizar os concursos para as conezias magistrais e doutorais (criadas pelo papa por solicitação do rei). De modo geral, embora os monarcas fossem expandindo o número de prebendas a que tinham direito de apresentação, o quadro reinol permanecia globalmente complexo e enredado (também pela prática de coadjutorias e renúncias, que podiam envolver venalidade). ${ }^{52}$

O padroado das ordens - que não incluía apenas o ultramar evidentemente - cumpriu na lógica da economia da mercê um papel fundamental. Fornecia uma ampla gama de recursos materiais e simbólicos controlados pela Coroa, aumentando consideravelmente a capacidade do centro político de recompensar e atrair vassalos servidores e lealdades diversas, incluindo

\footnotetext{
${ }^{50}$ Sobre os concursos e as diversas formas de provimento dos benefícios conferir RODRIGUES, Aldair Carlos. Igreja e Inquisição no Brasil: agentes, carreiras e mecanismos de promoção social. São Paulo: Alameda/ Fapesp, 2014, cap. 1 e 2.

${ }^{51}$ BNP, cód. 10887, p. 430-430v.

52 SILVA, Hugo Ribeiro da. O clero catedralício português e os equilíbrios sociais do poder (1564-1670). Lisboa: CEHR, 2013, p. 93-114. ALMEIDA, Fortunato de. História da Igreja em Portugal, vol 2. Porto: Portucalense, 1958, p. 57-58. DÍAZ RODRÍGUEZ, Antonio J. \& LÓPEZ-SALAZAR CODES, Ana Isabel, op. cit., p. 45-55.
} 
eclesiásticas. ${ }^{53}$ Sempre que interferia ou provia as prebendas das catedrais (e as vigararias paroquiais) do Atlântico estes gestos eram amplamente encarados como mercês nas mãos do rei português, especialmente quando não havia concurso. Do lado oposto, os suplicantes individuais e até as câmaras também jogaram aqui algumas das suas estratégias políticas.

Em razão de os cabidos abrigarem boa parte da elite eclesiástica das dioceses e em consequência da importância simbólica das catedrais, a pressão dos notáveis e intermédios pelo controlo das respetivas prebendas era feita em conjunto com a luta pela disputa dos órgãos do poder civil e militar. E estava longe de ser uma questão menor. As câmaras atlânticas dos espaços estudados envolveram-se elas próprias no referido controlo. Seria uma forma de as elites e grupos intermédios locais garantirem que podiam assegurar estes postos para os seus filhos.

Na Madeira, este processo foi bem claro e começara cedo, em 1513, quando o bispado ainda não estava ereto. Foi, aliás, assunto que mereceu ao longo do tempo forte atenção. Em 1755, a Câmara do Funchal pediu a d. José a confirmação dos diplomas anteriores sobre a temática, e o alvará resultante foi registado na Chancelaria da Ordem de Cristo como meio de garantir a sua perenidade. O seu conteúdo é bem explícito sobre a importância desta matéria:

...atendendo ao que me representaram os vereadores da câmara da cidade do Funchal da Ilha da Madeira sobre que pela certidão que juntaram se via ter o senhor rei D. Manuel privilegiado aos naturais daquela Ilha preferindo-os a outros quaisquer para a ocupação das conezias benefícios, e mais ocupações eclesiásticas por alvará de 20 de Março de 1513 cuja graça tinham confirmado os senhores reis meus antecessores por alvarás de 30 de Agosto de 1570 e 20 de Março de 1605 e 14 de Maio de 1627 e 6 de Abril de 1640 os quais sempre haviam tido tanta observância que nomeando o bispo D. José de Sousa Castelo Branco a dignidade de chantre em seu irmão foram [sic] necessário que os oficiais da câmara haver assentição para se efectuar como consta de uma certidão que ofereceram ainda que ao depois os bispos foram dando menos cumprimento aos ditos privilégios provendo nos benefícios aos sujeitos que consigo levavam para aquele bispado. ${ }^{54}$

Note-se que o diploma de 1627, cuja cópia estava registada no arquivo do município, foi incluída em Memórias seculares e eclesiásticas da diocese que compilou o madeirense Henrique Henriques de Noronha, em $1722 .{ }^{55} \mathrm{Na}$ eco-

\footnotetext{
53 OLIVAL, Fernanda. As ordens militares e o Estado moderno: honra, mercê e venalidade. Lisboa: Estar, 2001, p. 44.

${ }^{54}$ ANTT. Chancelaria da Ordem de Cristo, livro 274, f. 178-179.

${ }^{55}$ NORONHA, Henrique Henriques de, op. cit., p. 152, 496.
} 
nomia das Memórias, o documento em causa reafirmava o estatuto das elites locais, a par dos homens ilustres que ali tinham nascido (bispos, varões insignes nas letras, na santidade ou que ocuparam títulos e postos militares) ou do inventário dos apelidos nobres da terra. A obra também representava um intento de busca de identidade, pelo que aquele diploma não podia faltar.

Como se depreende do documento de 1755, a nomeação do chantrado em Manuel da Cunha Pinheiro, por volta de 1708, mesmo tendo o indigitado uma carreira inquisitorial desde 1701 e sendo meio-irmão do bispo Castelo Branco, exigira a anuência do município. A Câmara do Funchal assumia-se como guardiã da terra e dos seus postos relevantes.

O prelado que se seguiu ao que se acaba de citar, d. frei Manuel Coutinho (1725-1741), freire conventual da Ordem de Cristo, foi muito ousado. Tentou ser não só reformista quanto chegou ao arquipélago com uma clientela de gente do reino para colocar em lugares eclesiásticos, e fê-lo. Por um motivo e por outro teve de suportar grandes diferendos, tanto por parte de membros capitulares, como da câmara e de outros agentes locais. ${ }^{56}$ Conhecem-se pelo menos 11 desses elementos da família do bispo ${ }^{57}$ e todos eles alcançaram bons lugares. A ascensão de Bernardo Rodrigues Nogueira foi mesmo fulgurante nestes 16 anos e merece ser analisada. Era natural da Beira (Santa Marinha), formou-se em Cânones (1719) e ainda nesse ano e enquanto estudante conseguiu aprovação para familiar do Santo Ofício. Teve, contudo, de habilitar também um filho natural, nascido em 1714 de uma relação fortuita com uma criada dos pais. Cinco anos depois, quando fez petição para comissário, alegou: "e depois de eclesiástico foi provido em um dos Arciprestados do dito Bispado [de Coimbra] e de presente está nomeado pelo Ilustríssimo Bispo do Funchal para seu vigário geral e porque desejar ir condecorado com a ocupação de comissário do Santo Ofício (...)". Era desta forma, para partir de Lisboa mais autorizado, que solicitava o cargo inquisitorial. Efetivamente quando lhe foi emitida provisão de comissário, em 12 de outubro desse ano, já era provisor, vigário geral, juiz dos resíduos e das habilitações de genere da diocese madeirense. ${ }^{58}$ Não jurou em Lisboa a incumbência do Santo Ofício, por se encontrar já no Funchal. ${ }^{59}$ Acompanha-

\footnotetext{
${ }^{56}$ TRINDADE, Ana Cristina M. Plantar nova christandade: um desígnio jacobeu para a diocese do Funchal - frei Manuel Coutinho, 1725-1741. Funchal: Drac, 2012.

${ }^{57}$ Ibidem, p. 53-60.

${ }^{58}$ Ibidem, p. 55.

${ }^{59}$ ANTT. Inquisição de Lisboa, livro 111, f. 135.
} 
ra o novo prelado. Ainda em julho de 1725 fora apresentado numa conezia da Sé do Funchal ${ }^{60}$ e no ano seguinte chegou a mestre-escola. ${ }^{61}$ Esta última nomeação, feita pelo bispo, concitou forte oposição por parte da Câmara do Funchal. O município impugnou-a na Mesa da Consciência e Bernardo Rodrigues Nogueira demorou até poder entrar na posse da dignidade (1731). ${ }^{62}$ Suspeita-se que outro cônego natural da Madeira e bem-nascido, Bartolomeu César de Andrade, pretendia o lugar e até acusava o prelado de não fazer provimentos em fidalgos, "devendo eles estar primeiro que os outros". ${ }^{63}$ Pelo menos no ano de 1730, Bernardo Rodrigues Nogueira já era visitador do Ordinário no oeste e no norte da Madeira, mais em concreto na Ponta do Sol, Fajã da Ovelha, Porto Moniz, Seixal e Ponta Delgada. No ano seguinte, de novo em Ponta Delgada e em S. Jorge. ${ }^{64}$ Por fim, em 1732, Bernardo Rodrigues Nogueira chegou a arcediago, a segunda dignidade mais alta do cabido, ${ }^{65}$ justamente até onde o bispo tinha poderes para fazer provimentos. Também Antônio Mendes de Almeida, filho de pais mecânicos, natural de Coimbra, fez um percurso muito rápido. Chegou com o prelado sem quaisquer ordens e na Madeira recebeu as menores (outubro de 1726) e as de missa (abril de 1727). Em 1730, já era visitador. Dois anos depois tinha meia conezia na Sé do Funchal e, em 1735, iniciou o processo de habilitação para comissário do Santo Ofício, quando já era escrivão da Câmara Eclesiástica do Funchal. Chegaria a cônego de prebenda inteira em 1738 e a comissário do Santo Ofício em 1742. ${ }^{66}$ Tal como Bernardo Rodrigues Nogueira, o fato de ser bacharel formado em Cânones também lhe facilitou a ascensão e não terá sido totalmente indiferente para a chegada de ambos a comissários do Santo Ofício. Mais nenhum elemento dos comensais de d. Manuel Coutinho terá pedido distinção afim, nem a obtiveram.

Este bispo promoveu muito na Madeira um teólogo natural de Ourém e freire conventual da Ordem de Cristo, que também fazia parte do seu séquito: frei Bonifácio de Faria. Era frei Bonifácio confessor de d. frei Manuel

\footnotetext{
${ }^{60}$ ANTT. Chancelaria da Ordem de Cristo, livro 157, f. 366.

${ }^{61}$ Ibidem, livro 173, f. 294.

${ }^{62}$ TRINDADE, Ana Cristina M., op. cit., p. 55.

63 Ibidem, p. 151, 161.

${ }^{64}$ Ibidem, p. 300.

65 ANTT. Chancelaria da Ordem de Cristo, livro 204, f. 307.

${ }^{66}$ Sobre esta carreira TRINDADE, Ana Cristina M., op. cit., p. 57-58, 176, 301; ANTT, HSO. António, maço 91, doc. 1708; ANTT. Chancelaria da Ordem de Cristo, livro 204, f. 308-308v, livro 206, f. 248v; ANTT. Inquisição de Lisboa, livro 114, f. 69v
} 
rev. hist. (São Paulo), n. 175, p. 25-67, jul.dez., 2016 http://dx.doi.org/10.11606/issn.2316-9141.rh.2016.124067
Aldair Carlos Rodrigues \& Fernanda Olival

Reinóis versus naturais nas disputas pelos lugares eclesiásticos do Atlântico português: aspectos sociais e políticos (século XVIII)

Coutinho, pároco e diretor espiritual da sua família e seu esmoler. Chegou a examinador sinodal, pregador, juiz das justificações de genere e a visitador de alguns conventos. Por fim, quando em 1734 ficou vago o chantrado da Sé do Funchal, por morte de Manuel da Cunha Pinheiro, foi ele a pessoa escolhida para o substituir na dignidade capitular. ${ }^{67}$ Se a nomeação não despertou larga oposição no Funchal, quando em 1741 o bispo veio para Lisboa, pois estava provido no bispado de Lamego, a correspondência do cabido mostra bem a relutância contra os que não eram naturais. Tudo se agravava quando também não eram residentes ou deixavam de o ser e eram titulares de benefícios com prebenda.

Com efeito, em 1742, as cartas do procurador do cabido da Sé do Funchal em Lisboa exibem bem a preocupação contra os três elementos capitulares que tinham acompanhado d. Manuel Coutinho no seu regresso ao reino: o arcediago Bernardo Rodrigues Nogueira, o chantre Bonifácio e um meio-cônego natural de Sesimbra, chamado Filipe de Oliveira Maia. Em 20 de agosto, escrevia:

Tenho proposto este negócio do reverendo Arcediago, e consultado não só letrado douto, mas experiente ministro da Mesa da Consciência para que me insinuassem o meio mais sumário para obrigar ou a que vão residir nos seus benefícios os três capitulares que dessa sé se acham neste reino, ou a que larguem os mesmos benefícios, e me asseguram que com facilidade se pode isso fazer requerendo-se a Sua Majestade pela Mesa da Consciência com justificação de que no reino se acham, seja servido mandá-los notificar para o referido efeito pois desta diligência se há-de seguir infalivelmente uma das 2 coisas ou ir logo, ou largar logo, e assignando-se-me mais de 20 exemplos sucedidos há bem poucos anos na Mesa com vários capitulares de todo o ultramar.

Ao mesmo tempo realçava sem grande sentimento a morte do bispo d. Manuel Coutinho e como isso ajudaria a resolver o problema: "os três que cá se acham, suponho que já sem bispo porque aqui se diz ser falecido o de Lamego, notícia que ainda necessita de confirmação, sem embargo de ser certo o nomear-se há poucos dias para bispo coadjutor de Lamego o prior dos religiosos de Tomar". Retomava o assunto em novembro do mesmo ano:

agora se concluirá esta pendência com maior brevidade pois a morte do Excelentíssimo bispo de Lamego totalmente fez cessar o fundamento do dito reverendo arcediago, o qual se acha na Serra da Estrela, sua pátria sem tenção (segundo se me assegura) de se recolher a essa ilha: o mesmo se me diz do reverendo chantre pois além de ter com-

\footnotetext{
${ }^{67}$ Sobre este percurso TRINDADE, Ana Cristina M., op. cit., p. 56-57, 275.
} 
prado umas moradas de casas em Ourém, donde se acha descansando no seu natural, tem contraído amizade grande com o bispo eleito de Lamego, que também é frade de Tomar, e se intende que irá com ele. O meio cônego Filipe de Oliveira está em Lisboa dizendo a todos que na primeira ocasião se recolhe a essa ilha: se vossa senhoria entender que obro bem em mandar citar estes 3 sujeitos para que se recolham aos seus benefícios ou larguem, como lhe avisei na minha primeira carta, de que ainda não tive resposta, com seu aviso o farei (..... ${ }^{68}$

O caso de Bernardo Rodrigues Nogueira revelar-se-ia o mais complexo. Na realidade, em 1741, alcançara um diploma papal que lhe permitira usufruir dos frutos do seu benefício madeirense por um biênio, exercendo a ocupação que tinha em Lamego, que era uma vez mais de vigário-geral. ${ }^{69}$ Entretanto, fora para aquela cidade, de novo na companhia do seu protetor. Em 1745, foi apontado bispo de São Paulo (seria o primeiro da nova diocese) e ainda litigava pelos rendimentos insulares. Do outro lado da contenda estava o cabido da Sé do Funchal, que continuava a opor-se. ${ }^{70}$ Em janeiro de 1745, os capitulares funchalenses também citaram judicialmente o chantre ausente. Este, no entanto, alegou que saíra da Madeira a 8 de abril de 1741 com autorização do cabido para tratar da sua saúde e que renovara a permissão por igual período, no tempo adequado, por não registar melhoras. Apesar de ter desistido dos frutos da sua dignidade a partir de 1 de janeiro de 1743 , acabou sentenciado na perda do título de chantre em 1747 . $^{71}$

Efetivamente, nos cabidos atlânticos mais elitistas e fechados, uma das vias de entrada dos reinóis consistia em chegar nas dioceses inseridos no séquito dos novos bispos. Com o amparo do prelado, o ingresso na hierarquia da Igreja era muito mais fácil, sendo possível, por exemplo, a obtenção de lugares nos cabidos ou nos postos elevados da administração diocesana. Passava-se o mesmo na Bahia. O minhoto José Rodrigues de Oliveira, por exemplo, chegou junto com um dos arcebispos - d. Luís Álvares de Figueiredo (1725-35) -, e passou a secretariar o antístite e a residir com ele no palácio episcopal. Essa relação seguramente fora tecida em Braga, cidade onde o jovem padre nascera em 1698 e onde estudara, e local onde o prelado havia sido bispo auxiliar. Quatro anos após o seu desembarque na Bahia, o padre

\footnotetext{
${ }^{68}$ ANTT. Cabido da Sé do Funchal, maço 9, doc. 38

${ }^{69}$ ANTT. Cabido da Sé do Funchal, maço 9, doc. 37.

${ }^{70}$ ANTT. Cabido da Sé do Funchal, maço 8, doc. 23.

${ }^{71}$ ANTT. Cabido da Sé do Funchal, maço 8, doc. 5.
} 
José Rodrigues de Oliveira já era cônego ${ }^{72}$ e, em 1732, chegava a comissário do Santo Ofício. Por essa altura, já tinha um papel importante na promoção da mobilidade de outros membros de sua parentela bracarense. Do Brasil, ele "manda dinheiro para sustentar um irmão que estuda em Coimbra e mandou recolher uma irmã em Braga".73 O cargo de comissário seria muitas vezes usado por estes acompanhantes adventícios como uma forma de os autorizar no novo espaço para onde iam. Tentavam jogar com o prestígio e o medo que o Santo Ofício exalava.

Sem o apoio direto dos bispos, os sacerdotes reinóis dificilmente conseguiriam entrar numa instituição muito almejada pela elite local como era o cabido da Bahia. ${ }^{74}$ Aliás, nestes territórios, onde normalmente o cabido era composto por naturais, os bispos que vinham de fora com clientela (grande ou pequena) representavam um risco. Não era por acaso que muitos prelados no século XVIII enfrentaram grande oposição na Madeira. Não só faziam descer o nível social de recrutamento dos capitulares, como retiravam recursos que os naturais consideravam seus.

Por isso mesmo, em diversos locais dos territórios em análise, as câmaras marcaram presença na reivindicação de garantias para os nascidos na terra. O procurador do munícipio de Angra às Cortes de Lisboa de 1642 levou capítulos particulares onde o assunto era colocado:

Que Vossa Magestade nos faça mercê mandar nomear Bispo (...) e ordenar ao que for eleito, e os mais que succederem que provejam as Dignidades, Vigairarias, e mais Benefícios daquele Bispado nos naturais dele, conforme as qualidades, partes, e suficiência de cada um assim como o ordenou por uma provisão o Senhor Rei Dom Sebastião. ${ }^{75}$

Uma súplica da câmara do Rio de Janeiro dirigida ao rei d. Pedro em finais do século XVII, e citada por Fernanda Bicalho, é muito esclarecedora. Naquela, os vereadores do Rio de Janeiro solicitavam que os "moradores naturais do Estado do Brasil, sendo idôneos" fossem preferidos aos reinóis nos postos de guerra, ofícios, conezias e dignidades que vagassem naquele

\footnotetext{
${ }^{72}$ Foi apresentado na conezia a 1 de setembro de 1729. ANTT. Chancelaria da Ordem de Cristo, livro 192, f. 349.

${ }^{73}$ Enviara o dote para esta irmã entrar no convento do Salvador. ANTT, HSO. José, maço 35, doc. 566 , f. não numerado.

${ }^{74}$ SILVA, Cândido da Costa. Os segadores e a messe: o clero oitocentista na Bahia. Salvador: Edufba. 2000, p. 144.

75 MALDONADO, pe. Manuel Luis. Fénix angrense, vol. 2. Angra do Heroísmo: Instituto Histórico da Ilha Terceira, 1990, p. 268.
} 
Estado. ${ }^{76}$ A representação foi acatada pelo Conselho Ultramarino e recebeu despacho positivo do monarca. ${ }^{77}$

O requerimento da câmara do Rio de Janeiro possuía teor semelhante ao que fora incluído no capítulo 2 oferecido em cortes (1668) pelo procurador do Estado do Brasil, de acordo com documentos compilados por Pizarro e Araújo. O desfecho resultou no decreto régio de 3 de julho de 1668, por meio do qual o monarca "mandou prover nos postos vagos de Milícia do mesmo Estado, os que somente nele tivessem servido a Sua majestade; nos seus moradores, os ofícios de justiça e fazenda e nos filhos destes, as conezias e dignidades" ${ }^{78}$ Esta hierarquia era assaz expressiva e procurava contentar todos os intervenientes, incluindo os descendentes.

Cerca de três anos depois da criação da diocese do Rio de Janeiro, a provisão de 4 de março de 1679 ordenava que se preferissem os naturais no provimento do cabido e este diploma registrou-se nos livros do município. ${ }^{79}$

Esta era, com efeito, uma aspiração muito presente na América portuguesa, desde pelo menos meados do século XVII. Num livro do deputado da Mesa da Consciência, Lázaro Leitão Aranha, que compilava as decisões mais importantes do arquivo daquela instituição sobre o padroado da Ordem de Cristo no ultramar, até cerca do começo da década de 1730, fez-se uma síntese muito clara:

Pedindo os moradores da Bahia, que no concurso às igrejas benefícios e conezias, preferissem sempre os naturais, se resolveu, que concorrendo iguais merecimentos prefiram os naturais 14 de Julho de 1652, maço 12 e o mesmo no Rio de Janeiro tendo a limpeza de sangue 24 de Janeiro de 1679, maço 12 e já se tinha o mesmo mandado em declaração do capítulo de cortes, em consulta de 19 de Abril de 1675, maço 12, e queixando o cabido do Rio de se proverem por decretos algumas igrejas em pessoas naturais do Reino sem proceder oposição, respondeu El-Rei estavam bem providas, e que a resolução da consulta de 24 de Janeiro de 1679, não proíbe, que os naturais deste

\footnotetext{
${ }_{76}$ AHU. Documentos avulsos do Rio de Janeiro, caixa 4, doc. 105 e 106. Apud: BICALHO, Maria Fernanda Baptista. Conquista, mercês e poder local: a nobreza da terra na América portuguesa e a cultura política do Antigo Regime. Almanack Brasiliense, n. 2, São Paulo, nov. 2005, p. 32 (negrito nosso).

77 AHU. Documentos avulsos do Rio de Janeiro, caixa 4, doc. 105 e 106. Apud: BICALHO, Maria Fernanda Baptista. Conquista, mercês e poder local, op. cit., p. 32 (negrito nosso).

${ }^{78}$ ARAÚJO, José de Souza Azevedo Pizarro. Memórias históricas do Rio de Janeiro, vol. 6. Rio de Janeiro: Imprensa Nacional, 1946, p. 236-237 (negrito nosso).

${ }^{79}$ Ibidem, p. 237.
} 
rev. hist. (São Paulo), n. 175, p. 25-67, jul.dez., 2016 http://dx.doi.org/10.11606/issn.2316-9141.rh.2016.124067
Aldair Carlos Rodrigues \& Fernanda Olival

Reinóis versus naturais nas disputas pelos lugares eclesiásticos do Atlântico português: aspectos sociais e políticos (século XVIII)

Reino possam pretender as igrejas dos bispados do Brasil 26 de Maio e 9 de setembro de 1723 maço $12 .{ }^{80}$

Infelizmente o maço em causa perdeu-se.

No início do século XVIII, os mais elevados estratos sociais das principais localidades litorâneas do Brasil - sobretudo aqueles setores com histórico de serviços ao rei e com voz nas câmaras - já haviam logrado seus intentos no que diz respeito à preferência dada aos naturais no preenchimento dos ofícios e benefícios do padroado, principalmente no que se reporta às prebendas catedralícias. ${ }^{81}$

Na Sé do Rio, entre os providos no século XVIII, apenas 13 clérigos eram originários do reino e um, dos Açores; os demais 58 (de um universo de 72 capitulares cuja naturalidade é conhecida) eram naturais da própria colônia (tabela 5). ${ }^{82}$

\section{Tabela 5}

\section{Naturalidade (conhecida) dos membros dos cabidos do Brasil providos no século XVIII}

\begin{tabular}{|c|c|c|c|c|c|}
\hline Cabido & $\begin{array}{c}\text { Reino e } \\
\text { ilhas }\end{array}$ & $\mathbf{\%}$ & Brasil & $\mathbf{\%}$ & Total \\
\hline $\begin{array}{c}\text { Rio de Janeiro } \\
(1701-1800)\end{array}$ & 14 & $19 \%$ & 58 & $81 \%$ & 72 \\
\hline $\begin{array}{c}\text { Mariana } \\
(1745-1808)\end{array}$ & 12 & $41 \%$ & 17 & $59 \%$ & 29 \\
\hline $\begin{array}{c}\text { São Paulo } \\
(1745-1808)\end{array}$ & 11 & $31 \%$ & 24 & $69 \%$ & 35 \\
\hline
\end{tabular}

Fonte: Rio de Janeiro: ARAÚJO, José de Souza Azevedo Pizarro. Memórias históricas do Rio de Janeiro, op. cit., p. 7-16, 67-176; AMCM-RJ. Livro de Tombo (1722-1840), caixa 95, unidade 1. ANTT, MCO. Padroados do Brasil, Bispado do Rio de Janeiro; ANTT, HSO. Mariana: TRINDADE, cônego Raimundo. A Casa Capitular de Mariana. Revista do Iphan, n. 9, Belo Horizonte, ano 1945, p. 217-246; TRINDADE, cônego Raimundo. A arquidiocese de Mariana. Subsídios para sua história. Belo Horizonte: Imprensa Oficial, 1953, p. 299-363; BOSCHI, Caio. Fixação dos textos, organização e estudo introdutório. O cabido da Sé de Mariana (1745-1820), Documentos básicos. Belo Horizonte: Fundação

\footnotetext{
${ }_{80}$ LC. Portuguese Mss., P187, f. LIV-LV.

${ }^{81}$ Para o caso da Bahia, conferir SILVA, Cândido da Costa, op cit., e também as habilitações do Santo Ofício dos cônegos e dignidades que se tornaram notários e comissários da Inquisição.

${ }^{82}$ Tais números abrangem todos os providos, independentemente do fato de terem chegado a estes postos por meio de concurso ou de decreto. ARAÚJO, José de Souza Azevedo Pizarro. Memórias históricas do Rio de Janeiro, op. cit., p. 7-16, 67-176; AMCM-RJ. Livro de Tombo (1722-1840), caixa 95, unidade 1. ANTT, MCO. Padroados do Brasil, Bispado do Rio de Janeiro; ANTT, HSO.
} 
rev. hist. (São Paulo), n. 175, p. 25-67, jul.dez., 2016 http://dx.doi.org/10.11606/issn.2316-9141.rh.2016.124067
Aldair Carlos Rodrigues \& Fernanda Olival Reinóis versus naturais nas disputas pelos lugares eclesiásticos do Atlântico português: aspectos sociais e políticos (século XVIII)

\begin{abstract}
João Pinheiro, Editora PUC-MG, 2011; TRINDADE, cônego Raimundo. Exercícios de pesquisa histórica, op. cit., p. 241-327; ANTT, HSO; ANTT, MCO. Padroados do Brasil, maço 5 e maço 6. São Paulo: ACM-SP. Colações do Cabido; ANTT, HSO; ANTT, MCO. Padroados do Brasil, Bispado de São Paulo, maço 10 e maço 11; Relação Geral da Dioceze de São Paulo, suas Comarcas, Freguesias, Congruas, Uzos e Costumes. Revista do Instituto Histórico e Geográfico de São Paulo, vol. 4, São Paulo, 1898-1899, p. 351-418.
\end{abstract}

Nos dois cabidos do interior, São Paulo e Mariana, ao invés, as bulas que erigiram suas dioceses, em 1745, não faziam exigência ou menção a respeito da naturalidade dos sacerdotes que seriam providos nas prebendas. No caso de Mariana, o bispo teria liberdade para selecionar os clérigos. ${ }^{83}$ Em virtude de Minas Gerais ser uma zona de ocupação relativamente recente, ainda não possuía, na altura, uma elite que pudesse reivindicar seus lugares (por meio de seus filhos) nestas instituições - como fizera a elite do Funchal desde bem cedo, a de Angra ou a do Rio de Janeiro nos finais de Seiscentos. Suas cadeiras catedralícias foram permeáveis aos reinóis até ao final da década de 1750. Entre 1747 e 1759, nove de onze clérigos cujas origens foram identificadas eram naturais de Portugal, sendo os outros dois oriundos da Bahia. Na década de 1760, não ocorreram novos provimentos e, no decênio seguinte, quando as vacaturas começaram a ser preenchidas, foi a vez de os sacerdotes nascidos em Minas Gerais dominarem as conezias e as dignidades. Dos 18 novos prebendados providos nas três décadas finais da centúria, 13 eram originários do próprio bispado (oito dos quais formados em Coimbra, quase sempre em Cânones) ${ }^{84}$ dois haviam nascido em outras capitanias e três, no reino. ${ }^{85}$

Em São Paulo, a elite da região fez pressão para que o primeiro prelado desse preferência aos naturais da terra no preenchimento das cadeiras do cabido, seguindo o exemplo do Rio de Janeiro. Eram os feitos dos paulistas nas descobertas das jazidas de ouro durante os anos finais do século XVII, no

\footnotetext{
${ }^{83}$ BOSCHI, Caio. Os escritos de d. frei Manuel da Cruz e as Constituições Primeiras do Arcebispado da Bahia. In: FEITLER, Bruno \& SOUZA, Evergton Sales (org.). A Igreja no Brasil: normas e práticas durante a vigência das Constituições Primeiras do Arcebispado da Bahia. São Paulo: Ed. Unifesp, 2011, p. 399-424; FEITLER, Bruno \& SOUZA, Evergton Sales Exercícios de pesquisa histórica. Belo Horizonte: Editora da PUC-Minas, 2011, p. 241-298.

${ }^{84}$ AUC. Ficheiro das matrículas e exames (índice por ordem alfabética de sobrenome).

${ }^{85}$ TRINDADE, cônego Raimundo. A Casa Capitular de Mariana. Revista do Iphan, n. 9, Belo Horizonte, 1945, p. 217-246; FEITLER, Bruno \& SOUZA, Evergton Sales. A Arquidiocese de Mariana. Subsídios para sua história. Belo Horizonte: Imprensa Oficial, 1953, p. 299-363; BOSCHI, Caio (fixação dos textos, organização e estudo introdutório). O cabido da Sé de Mariana (1745-1820). Documentos básicos. Belo Horizonte: Fundação João Pinheiro, Editora PUC-MG, 2011; FEITLER, Bruno \& SOUZA, Evergton Sales. Exercícios de pesquisa histórica, op. cit., p. 241-327; ANTT, HSO; ANTT, MCO. Padroados do Brasil, maço 5 e maço 6.
} 
rev. hist. (São Paulo), n. 175, p. 25-67, jul.dez., 2016 http://dx.doi.org/10.11606/issn.2316-9141.rh.2016.124067
Aldair Carlos Rodrigues \& Fernanda Olival Reinóis versus naturais nas disputas pelos lugares eclesiásticos do Atlântico português: aspectos sociais e políticos (século XVIII)

território que ficou conhecido depois como Minas Gerais, o argumento das súplicas camarárias endereçadas ao monarca nesse sentido, conforme documento citado por Cândido da Costa e Silva. Numa queixa de 1765, os camaristas alegavam que, naquele momento, das 14 prebendas da catedral, só cinco eram ocupadas por naturais do bispado, sendo que, no ano em que o cabido fora criado, nove sacerdotes, de um total de 14, eram nascidos na região paulista. ${ }^{86}$ Em perspectiva global, os naturais de São Paulo foram preponderantes no cabido (sobretudo entre os providos nos dois decênios finais da centúria): de um total de 35 capitulares cuja naturalidade é conhecida, 24 eram naturais da própria diocese, 10 eram originários do reino e um da Madeira. ${ }^{87}$

A maior permeabilidade dos cabidos de Mariana e São Paulo aos naturais de suas respectivas dioceses, por um lado, tem a ver com a progressiva sedimentação das hierarquias sociais nestas zonas que haviam sido profundamente impactadas pela descoberta do ouro. Os filhos dos patamares médios e superiores ali forjados começaram a entrar para a carreira eclesiástica nos finais da centúria, com maior intensidade. Por outro lado, tal quadro deve ser compreendido como o resultado da aplicação de uma medida legal adotada pela Coroa a partir de 1766, na Madeira e Açores, e posteriormente generalizada: a reserva dos benefícios do padroado da Ordem de Cristo para os naturais, mesmo perante a desigualdade dos mais requisitos.

${ }^{86}$ BA. 54-XIII-4, n. 46 (n. 1976 do inventário organizado por Alberto Ferreira). Apud SILVA, Cândido da Costa. Os segadores e a messe, op. cit., 2000, p. 144.

${ }^{87}$ ACM-SP. Colações do cabido; ANTT, HSO; ANTT, MCO. Padroados do Brasil, Bispado de São Paulo, maço 10 e maço 11; Relação Geral da Dioceze de São Paulo, suas Comarcas, Freguesias, Congruas, Uzos e Costumes. Revista do Instituto Histórico e Geográfico de São Paulo, vol. 4, São Paulo, 1898-1899, p. 351-418. Ao longo do tempo, a naturalidade dos clérigos que entraram no cabido de São Paulo foi a seguinte: 1745-50: 9 paulistas, 4 reinóis; 1751-60: 4 paulistas, 1 reinol; 1761-70: 1 paulista, 2 reinóis; 1771-80: nenhum provimento; 1781-90: 6 paulistas, 3 reinóis; 1791-1800: 4 paulistas, nenhum reinol, 1 madeirense. 
rev. hist. (São Paulo), n. 175, p. 25-67, jul.dez., 2016 http://dx.doi.org/10.11606/issn.2316-9141.rh.2016.124067
Aldair Carlos Rodrigues \& Fernanda Olival Reinóis versus naturais nas disputas pelos lugares eclesiásticos do Atlântico português: aspectos sociais e políticos (século XVIII)

A questão emergiu a propósito daqueles arquipélagos e criou jurisprudência no resto do espaço atlântico ${ }^{88}$ e, provavelmente, para além dele. ${ }^{89}$ Reporta-se ao alvará de 29 de agosto de 1766. Neste começava-se por relembrar que nos preâmbulos dos diplomas que davam poderes aos bispos

para os referidos provimentos, se continham as significantes palavras de nomearem eles para as dignidades benefícios e igrejas pessoas idôneas dos respetivos bispados, para os naturais deles procurarem habilitar-se, e exercitar-se em letras, e virtudes vendo que por estas qualidades haviam de ser providos nas tais dignidades benefícios e igrejas.

\section{No entanto, porque estas diretivas estavam esquecidas e}

diferentes prelados das mesmas ilhas fizeram nomeações em pessoas de fora delas, umas vezes indignas e outras menos beneméritas sem precederem editais, nem exames públicos (...) tomando-se para as referidas transgressões por pretexto a cláusula de que os provimentos de naturais se fariam, quando entre eles, e os outros opositores houvesse igualdade nos merecimentos, e nas mais partes [sic].

O alvará reafirmava que tal interpretação não era adequada à Madeira (ou às "ilhas Terceiras, vulgarmente chamadas dos Açores" no documento enviado a Angra): ${ }^{90}$

não é adaptável à ilha da Madeira na qual pelo grande número de casas nobres e distintas por nascimento, e pelas suas vastas povoações, não cabe no possível, que faltem jamais eclesiásticos dignos, e beneméritos para ocuparem os lugares de dignidade e

\footnotetext{
${ }^{88}$ Esta era uma prática recorrente na gestão centralizada dos benefícios do padroado da Ordem de Cristo pela Mesa de Consciência e Ordens. Ou seja, o que se decidia para uma diocese ultramarina acabava repercutindo nas demais pela criação de precedentes. Por exemplo, por um decreto de 24 de janeiro de 1646, o monarca atendeu a uma súplica do cabido de Angra para separar os cargos episcopais (que passariam a ser providos pelos bispos) do direito de apresentação das prebendas dos cabidos e dos benefícios paroquiais (vigararias). A medida foi seguida posteriormente nos bispados do Brasil e referenciada em consultas. O alvará de 1646 pode ser consultado em: http://www.iuslusitaniae.fcsh.unl.pt/verlivro.php?id_parte=99\&id_obra=63\&pagina=767. Sobre sua influência no Brasil, ver: ANTT, MCO. Padroados do Brasil, Bispado de São Paulo, maço 11. Consulta sobre a mercê do ofício de escrivão da Câmara Episcopal da Diocese de São Paulo que pede Manuel Joaquim de Ornelas (01/10/1796).

${ }^{89}$ Veja-se o eco em Bardes, na Índia, em abril de 1768. ANTT, com, livro 319, f. 21-27.

${ }^{90}$ Cada uma das duas dioceses insulares terá recebido um alvará rigorosamente igual com adaptação nos topônimos inerentes. O de Angra encontra-se reproduzido em DRUMMOND, Francisco Ferreira. Anais da ilha Terceira, vol. III, reed. Angra do Heroísmo: Secretaria Regional da Educação e Cultura do Governo dos Açores, 1981, letra M.
} 
cônegos da catedral com decência e com serviço da sé, ou clérigos de letras e virtudes que sirvam as igrejas paroquiais com zelo do aumento do culto divino, e de aproveitamento espiritual dos fregueses que são mais para esperar destes pastores próprios, naturais do que dos outros estranhos, e por tais mercenários.

Perante o quadro traçado, o documento estabelecia que naquela ilha "não possa ser nomeado para as dignidades, canonicatos, benefícios, e igrejas clérigo algum que não seja nascido dentro dos respetivos territórios da diocese do Funchal". Para o efeito devia sempre efetuar-se concurso. No alvará idêntico recebido por Angra, onde estava Madeira, colocava-se Angra ou Açores.

O alvará em causa era mandado registar na Secretaria da Ordem de Cristo (na Mesa da Consciência), "para que no caso de chegarem quaisquer nomeações feitas contra o acima ordenado em parte ou em todo se lhe não expeçam as confirmações". Devia também ficar assente na Câmara Eclesiástica de Angra e do Funchal e no arquivo de cada um dos municípios. A justificação de um diploma tão taxativo era esclarecedora: "porque assim se faz necessário para serviço de Deus, e meu e consolação dos moradores da referida ilha justamente aflitos com a vexação de verem com fome comer aos estranhos o pão, que a eles lhes toca por todos os sobreditos títulos".91

No caso do Brasil, após 1766, os preâmbulos dos alvarás régios que autorizavam os bispos a abrirem concursos para preenchimento das vacaturas dos cabidos e das vigararias coladas passaram a enfatizar a exigência de os opositores serem nascidos nos bispados onde os benefícios fossem ser disputados. Em correspondência dirigida ao bispo de Mariana em 1779, por exemplo, d. Maria especificava que, além das qualidades exigidas para os cargos, "serão os ditos propostos naturais desse vosso bispado enquanto os houver". Dentre os naturais, "preferindo entre eles, em igualdade de circunstâncias, os que forem da antiga nobreza dessa capitania por procederem dos primeiros descobridores, que a custa do seu sangue concorreram para nessas regiões se plantar a vossa santa fé e se propagar a luz do evangelho".92 Este documento veio também reforçar a ideia de antiguidade e o tipo de ancienidade que devia estruturar as hierarquias sociais naquele território. O dar preferência à nobreza seria um meio de evitar o problema

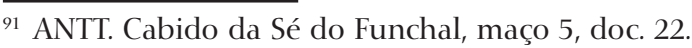

${ }^{2}$ ANTT, MCO. Padroados do Brasil, Bispado de Mariana, maço 5. Alvará de 23 de julho de 1779. Alvará porque Vossa Majestade é servida regular os provimentos das dignidades, conezias, e mais benefícios da Sé da cidade de Mariana, como também os das paróquias, vigararias, e mais benefícios curados, e sem cura daquele bispado (negrito nosso).
} 
dos nativos e a questão da cor da pele. Como o alvará de 1766 também se aplicou a S. Tomé, ali não faltaram cônegos negros, pois a diocese era pouco atrativa para quem estava longe. ${ }^{93}$ Nos arquipélagos dos Açores e da Madeira, por exemplo, a questão da nobreza não se colocou da mesma forma. Em 1767-1768, num concurso para uma conezia no Funchal, dois pretendentes tentaram alegar o grau de nobreza como um argumento decisivo e acabou provido o que tinha maior ciência, não obstante a maior nobreza de outros. ${ }^{94}$ Na realidade, o inequívoco primado da naturalidade nas dioceses do Atlântico teve uma aplicação diferenciada e o mesmo se diga das suas implicações.

Em 1782, houve uma ligeira flexibilização quanto ao radicalismo da medida de 1766, abrindo brecha para que os forasteiros que já residissem nas dioceses pudessem se opor às suas vacaturas, assim como os que haviam se ordenado no Brasil como "compatriotas". 95 No quadro global, no entanto, estas brechas foram pouco eficazes, visto que os benefícios eram cada vez mais apropriados pelos clérigos nascidos nos próprios bispados ultramarinos, à semelhança também do que se passava nas dioceses metropolitanas. De naturais da terra, a exigência passou a ser cada vez mais de recrutamento entre os naturais do bispado como se consagrou plenamente em 1766. Tudo isto contribuía para gerar uma crescente identidade regional em territórios compostos por várias dioceses. Estas oportunidades e o efeito disciplinador a médio e longo prazo dos bispados fazia com que os grupos intermédios, atentos às vias de ascensão social, optassem por encaminhar os rebentos masculinos para o clero e casar as filhas. ${ }^{96}$ Ali conquistavam poder para si, para os ascendentes e sobretudo para os vindouros e colaterais. Susana Goulart Costa refere o exemplo expressivo de um capitão açoreano que tendo três filhos e pretendendo que todos seguissem a carreira sacerdotal, apenas um obedeceu. Como consequência, apenas esse foi nomeado como herdeiro da terça, por ser "o único que nos fez a vontade em ser sacerdote",

\footnotetext{
${ }_{93}$ FIGUEIRÔA-RÊGO, João \& OLIVAL, Fernanda. Cor da pele, distinções e cargos: Portugal e espaços atlânticos portugueses (séculos XVI a XVIII). Tempo, vol. XVI, nº 30, 2011, p. 135-136, 143.

${ }^{94}$ ANTT, MCO. Livro 319, f. 37v-40.

${ }^{95}$ Alvará de 12 de fevereiro de 1782. ANTT, MCO. Padroados do Brasil, Bispado de Mariana, maço 5. Casos houve de pedido de dispensa da falta de naturalidade; veja-se exemplo de 1769, num concurso respeitante ao Pará e ao qual pretendia opor-se um clérigo natural da Madeira. ANTT, MCO, livro 319, f. 109v-111.

${ }^{96}$ No mesmo sentido, RODRIGUES, Aldair Carlos, op. cit., p. 56. Esta análise é válida para os segmentos que reservaram filhos para o clero secular, sobretudo. No caso dos recolhimentos femininos, consultar ALGRANTI, Leila. Honradas e devotas: mulheres da colônia. Rio de Janeiro: José Olympio, 1993, cap. 4.
} 
explicavam os progenitores. ${ }^{97}$ A atitude dos pais revela bem a importância que davam à opção pelo sacerdócio.

O diploma de 1766 foi inúmeras vezes citado e invocado na legislação posterior. A relevância deste alvará pode ser compreendida, por um lado, como resultado da pressão latente das elites locais pelo domínio da grelha beneficial através de seus rebentos, e, por outro, como parte das políticas reformistas de Sebastião José de Carvalho e Melo. No reinado de d. José, procurou-se dar mais protagonismo aos naturais do Brasil, por exemplo, e também houve uma inflexão na política de cooptação das elites locais dentro dos projetos de colonização. ${ }^{9}$ Por fim, é importante olhar para este alvará no remate de uma política que vinha do começo do século XVII, segundo a qual o império ultramarino devia bastar-se a si próprio. Isto é, em matéria de economia da mercê, e por conseguinte de distinção, fizera-se cimentar a ideia de que os serviços locais deviam ter recompensas locais, de modo a evitar que o servidor se deslocasse para o reino, abandonando as suas funções. Esta foi também uma política de incentivo à fixação de colonos no espaço ultramarino português, globalmente considerado. Ora, à medida que esses grupos se enraizaram por gerações sucessivas a nível colonial, eram cada vez mais encarados pela Coroa portuguesa como "locais", quase como se fossem nativos. No entanto, estes elementos tinham plena consciência da sua importância estratégica no plano local e regional para os projetos expansionistas da monarquia, quer do ponto de vista da defesa, quer da administração (incluindo-se nesta a questão religiosa). A recuperação de Angola e, sobretudo, do nordeste açucareiro da América portuguesa, na guerra contra os holandeses, fora fulcral para incutir este sentimento no espaço atlântico.

Portanto, no âmbito eclesiástico atlântico, a fratura naturais / reinóis cumpria um papel relevante nos equilíbrios sociais e políticos. Permeou as relações entre a Coroa e os segmentos intermédios e elitistas em constituição do espaço português considerado. A conotação política adquirida pela cliva-

\footnotetext{
${ }_{97}$ COSTA, Susana Goulart, op. cit., p. 113.

${ }^{98}$ Em termos sociais e demográficos, o projeto de Pombal visava dar mais protagonismo aos sujeitos nascidos no Brasil, de modo a dinamizarem o processo de colonização e defenderem a conquista pelo aumento de sua população. Para tanto, no âmbito da lei, procurava-se diminuir os entraves que poderiam desencorajar a miscigenação ou eliminar aspectos que desvalorizassem social e institucionalmente os colonos descendentes de indígenas. As influências das doutrinas austríacas que marcaram as medidas pombalinas preconizavam que parte importante do poder das formações políticas assentava-se em seu quantitativo populacional. MAXWELL, Keneth. Marquês de Pombal: paradoxo do Iluminismo. São Paulo: Paz e Terra, 1996, p. 53.
} 
gem em análise, em diferentes contextos (inclusive com a participação das câmaras municipais), relativiza o argumento de Nuno Monteiro que advoga a sua irrelevância até começos do século XIX.99

\section{Considerações finais}

Neste artigo privilegiou-se a clivagem naturais/reinóis como vetor principal de análise das características do clero presente no espaço atlântico português, enfocando os clérigos seculares dos Açores, da Madeira e do Brasil durante o século XVIII. Identificamos os traços principais do perfil dos sacerdotes que se habilitaram no Santo Ofício e de todos os que foram titulares de prebendas nos cabidos do centro-sul brasileiro (independentemente de serem membros da Inquisição ou não). O acesso aos lugares do poder eclesiástico foi condicionado por uma série de dinâmicas sociais e políticas.

Em perspectiva atlântica, o fenômeno apresentava variações e especificidades importantes. As fontes consultadas indicam que as elites da realidade insular se consolidaram e passaram a controlar o aparato eclesiástico desde muito cedo, dando estabilidade às configurações da clivagem naturais/forasteiros. As ameaças aos arranjos locais chegavam sobretudo com os clérigos que compunham os séquitos dos bispos, visto que disporiam de apoio do prelado para serem colocados em eventuais vacaturas, como se demonstrou sobretudo para a Madeira.

Na América portuguesa, encontramos ritmos diversos. O fato de ter sido habitada previamente por populações autóctones, ter o seu tecido social impactado fortemente pela escravidão e possuir fronteiras abertas e em movimento marcou o processo de estruturação dos grupos intermédios e das elites. A definição das naturalidades e suas clivagens estiveram sujeitas ao equilíbrio espacial do território, o qual se encontrava em constante redefinição, embora houvesse um grau mais avançado de decantação no litoral açucareiro, provido de importantes praças comerciais. No século XVIII, comparativamente, os clérigos reinóis encontrariam mais hipóteses de singrarem nas zonas que encabeçavam os eixos mais dinâmicos da colonização, nos quais as hierarquias sociais eram mais fluídas. Portanto, mais permeáveis à mobilidade social e à formação rápida de grupos intermédios por meio das carreiras eclesiásticas (entre outras hipóteses). Tal era o caso do centro-

\footnotetext{
${ }^{99}$ MONTEIRO, Nuno Gonçalo. A circulação das elites no império dos Bragança (1640-1808): algumas notas. Tempo, vol. 14, n. 27, 2009, p. 51-67.
} 
sul no contexto da intensa expansão das fronteiras no sentido oeste-interior-sul (principalmente após a descoberta de grandes jazidas auríferas nos territórios depois conhecidos como Minas Gerais, Goiás e Mato Grosso), movendo-se sempre em direção aos territórios espanhóis e ultrapassando as obscuras linhas do tratado de Tordesilhas. Nas regiões de colonização mais antiga, como eram as capitanias produtoras de açúcar com importantes grupos mercantis, os patamares sociais médios e superiores tendiam a estar comparativamente mais sedimentados, aproximando-se mais da realidade identificada para os arquipélagos atlânticos. Haviam forjado a tradição de se reproduzir socialmente por meio dos órgãos do poder eclesiástico, tendendo a fecharem-se aos forasteiros.

Em linhas gerais, à escala do Atlântico português, quanto maior fosse a distância (medida em histórica atratividade) das sedes episcopais e de Lisboa (rei/ mestre, Mesa da Consciência), maior abertura social haveria nos aparatos diocesanos; chegou ao ponto de haver falta de clérigos disponíveis ou aptos à ocupação dos cargos da rede paroquial (e até capitular) nas periferias mais inóspitas.

Numa abordagem de longa duração, como já muitas vezes tem sido dito a outros propósitos, ${ }^{100}$ a experiência insular funcionou como um laboratório inclusive para a gestão dos recursos do padroado da Ordem de Cristo na América. A ressonância das tensões e das pressões exercidas pelos patamares sociais mais destacados daqueles arquipélagos junto do centro político, e os encaminhamentos dados àquelas exigências, criaram os precedentes e os marcos reguladores que impactariam o Brasil e o resto do padroado ultramarino.

Em larga medida, tudo isto só foi possível graças à "gestão centralizada" dos recursos do padroado. Na dimensão periférica, as câmaras funcionavam como um vetor catalisador das dinâmicas locais no que respeitava à luta para influenciar os mecanismos de acesso aos benefícios eclesiásticos, sobretudo as prebendas e dignidades dos cabidos. A sua influência não deixava de se exercer por se tratar do campo religioso. O município era um órgão sensível aos interesses políticos dos grupos com destaque, fossem elites ou não tanto. Constituíram um importante vetor de pressão nestas relações de força. Eram, para estes grupos, um relevante canal de comunicação das periferias com o centro político do Império (leia-se: Mesa de Consciência e ordens, Conselho Ultramarino, secretários de Estado/monarca), mesmo que esta se fizesse de forma indireta.

\footnotetext{
${ }^{100}$ Veja-se, por exemplo, o modelo de expansão do açúcar no Atlântico a partir dos arquipélagos para o Brasil em: SCHWARTZ, Stuart. Segredos internos..., op. cit.
} 
A experiência "laboratorial" desenvolvida nas dioceses insulares e a criação de precedentes que impactavam todo o Atlântico teve muito a ver com a homogeneidade da jurisdição do padroado da Ordem de Cristo. Dava esta muitas vezes ao monarca (mestre da ordem) a palavra final quanto às linhas gerais que definiam o direito de apresentação dos clérigos nos benefícios. Não havia competição entre o rei e outras esferas de poder e jurisdição no que toca aos provimentos, como ocorria no espaço peninsular. Na realização das oposições para as vacaturas (cuja análise não está no escopo deste artigo, que enfoca os enquadramentos mais amplos e os efeitos sociais) os prelados cumpririam localmente um papel importante, em períodos de sede plena. ${ }^{101}$ Eram personagens que vinham sempre de fora e representavam tanto o conforto religioso como o poder de distribuir recursos e nem sempre este último era harmonizável com os interesses locais.

Na realidade, a disputa pelos lugares do poder eclesiástico e inquisitorial desempenhou um papel importante não só na formação e consolidação das elites locais (as elites "possíveis" em muitas dioceses brasileiras), como inclusivamente na definição política das identidades. Muitos desses atores envolvidos eram oriundos de setores intermédios, filhos de comerciantes, de artesãos, de lavradores e de gente das ordenanças. A ascensão social não retrocedia a muitas gerações. Em geral constituíam a segunda ou terceira, na qual o fenômeno se notava. No caso do nordeste açucareiro, do Rio de Janeiro e das ilhas seriam mais comuns os casos de maior recuo. No entanto, entrar para o cabido e ser comissário do Santo Ofício significava fazer parte da elite eclesiástica local e promover - de um só golpe - toda a parentela, mesmo a mais afastada.

No Funchal e em Angra, segmentos das elites e dos grupos intermédios não coincidiam de todo. Ali o cabido tinha um ou outro nobre e um ou outro fidalgo. No entanto, até o alvará de 29 de agosto de 1766, todos tendiam a invocar a bandeira de naturais / reinóis frente aos bispos e às suas clientelas, o que não significava que os bem nascidos esquecessem as suas origens e não as invocassem no dia a dia na instituição. Para estes, ser natural era apenas mais um argumento político oportuno, porque tinha alguma eficácia.

\footnotetext{
${ }^{101}$ Sobre os concursos e as diversas formas de provimento dos benefícios conferir RODRIGUES, Aldair Carlos. Igreja e Inquisição no Brasil..., op. cit., cap. 1 e 2.
} 
rev. hist. (São Paulo), n. 175, p. 25-67, jul.dez., 2016 http://dx.doi.org/10.11606/issn.2316-9141.rh.2016.124067
Aldair Carlos Rodrigues \& Fernanda Olival

Reinóis versus naturais nas disputas pelos lugares eclesiásticos do Atlântico português: aspectos sociais e políticos (século XVIII)

O alvará citado teve forte impacto social nos territórios mais miscigenados do Atlântico. No caso do Brasil, terá reforçado a disputa pela definição da nobreza possível nas várias regiões. Ajudou a incrementar em âmbito local o estatuto social dos grupos intermédios, aumentando as hipóteses de sua conversão em nobres ou serviu para criar essa ilusão.

\section{Referências bibliográficas}

ALGRANTI, Leila. Honradas e devotas: mulheres da colônia. Rio de Janeiro: José Olympio, 1993.

ALMEIDA, Fortunato de. História da Igreja em Portugal. Porto: Portucalense, 1958.

ARAÚJO, José de Souza Azevedo Pizarro. Memórias históricas do Rio de Janeiro, vol. 6. Rio de Janeiro: Imprensa Nacional, 1946.

BETHENCOURT, Francisco $\mathcal{E}$ CHAUDHRI, Kirti (dir.). História da expansão portuguesa, vol. 3. Lisboa: Temas e Autores e Debates, Círculo dos Leitores, 1998.

BICALHO, Maria Fernanda Baptista. Conquista, mercês e poder local: a nobreza da terra na América portuguesa e a cultura política do Antigo Regime. Almanack Brasiliense, n. 2, São Paulo, nov 2005, p. 32.

BLAJ, Ilana. A trama das tensões: o processo de mercantilização de São Paulo colonial (16811721). São Paulo: Humanitas; FFLCH/USP, 2002.

BORREgO, Maria Aparecida de Menezes. A teia mercantil. Negócios e poderes em São Paulo colonial (1711-1765). São Paulo: Alameda, 2010.

BOSCHI, Caio (fixação dos textos, organização e estudo introdutório). O cabido da Sé de Mariana (1745-1820). Documentos básicos. Belo Horizonte: Fundação João Pinheiro, Editora PUC-MG, 2011. (Coleção Mineiriana)

Os escritos de d. frei Manuel da Cruz e as Constituições Primeiras do Arcebispado da Bahia. In: FEITLER, Bruno \& SOUZA, Evergton Sales (org.). A Igreja no Brasil: Normas e práticas durante a vigência das Constituições Primeiras do Arcebispado da Bahia. São Paulo: Ed. Unifesp, 2011, p. 399-424.

Exercícios de pesquisa histórica. Belo Horizonte: Editora da PUC-Minas, 2011.

BOXER, Charles R. A Idade de Ouro do Brasil: dores do crescimento de uma sociedade colonial. São Paulo: Cia Editora Nacional, 1979.

BRAGA, Paulo Drumond. A Inquisição nos Açores. Ponta Delgada: Instituto Cultural, 1997.

CAMARGO, monsenhor Paulo Florêncio da Silveira. A Igreja na história de São Paulo (1745-1771), vol. 4. São Paulo: Instituto Paulista de História e Arte Religiosa, 1953.

CAMARINHAS, Nuno. Juízes e administração da Justiça no Antigo Regime. Portugal e o Império colonial, séculos XVII e XVIII. Lisboa: Fundação Calouste Gulbenkian, FCT, 2011.

TRINDADE, cônego Raimundo. A Casa Capitular de Mariana. Revista do Iphan, n. 9, Belo Horizonte, 1945, p. 217-246.

. A Arquidiocese de Mariana. Subsídios para sua história. Belo Horizonte: Imprensa Oficial, 1953, p. 299-363. 
rev. hist. (São Paulo), n. 175, p. 25-67, jul.dez., 2016 http://dx.doi.org/10.11606/issn.2316-9141.rh.2016.124067
Aldair Carlos Rodrigues \& Fernanda Olival

Reinóis versus naturais nas disputas pelos lugares eclesiásticos do Atlântico português: aspectos sociais e políticos (século XVIII)

COSTA, Susana Goulart. Viver e morrer religiosamente: a ilha de S. Miguel, século XVIII. Ponta Delgada: Instituto Cultural, 2007.

CUNHA, Mafalda Soares (org.). Do Brasil à metrópole: efeitos sociais (séculos XVII-XVIII). Separata da Revista Anais da Universidade de Évora, no 8 e 9, Évora, dezembro 1998/1999, p. 47-72.

DÍAZ RODRÍGUEZ, Antonio J. \& LÓPEZ-SALAZAR CODES, Ana Isabel. El cabildo catedralicio de Évora en la Edad Moderna (1547-1801). Historia y Genealogía, $\mathrm{n}^{\circ}$ 4, 2014, p. 42-43.

DRUMMOND, Francisco Ferreira. Anais da ilha Terceira, vol. III. reed. Angra do Heroísmo: Secretaria Regional da Educação e Cultura do Governo dos Açores, 1981.

FEITLER, Bruno. Nas malhas da consciência: Igreja e Inquisição no Brasil (Nordeste, 16401750). São Paulo: Alameda, Phoebus, 2007.

FIGUEIRÔA-RÊGO, João $\mathcal{E}$ OLIVAL, Fernanda. Cor da pele, distinções e cargos: Portugal e espaços atlânticos portugueses (séculos XVI a XVIII). Tempo, vol. XVI, no 30, 2011, p. 135-136.

FIGUEIRÔA-RÊGO, João. A honra alheia por um fio. Os estatutos de limpeza de sangue nos espaços de expressão ibérica (séculos XVI-XVIII). Lisboa: Fundação Calouste Gulbenkian, FCT, 2011.

FLORY, Rae $\mathcal{E}$ SMITH, David Grant. Bahian merchants and planters in the seventeenth and early eighteenth centuries. The Hispanic Historical American Review, 58 (4), 1978, p. 571-594.

HAUPT, Heinz-Gerhard. Comparative history - a contested method. Historisk Tidskrift, vol. 127, n. 4, 2007, p. 697-716.

HERZOG, Tamar. Naturales y extranjeros: sobre la construcción de categorías en el mundo hispánico. Cuadernos de Historia Moderna, vol. 10, Madri, 2011, p. 23, 31.

KENNEDY, John Norman. Bahian elites, 1750-1822. The Hispanic Historical American Review, 53 (4), 1973, p. 415-439.

KOCKA, Jürgen. Comparison and beyond. History and Theory, vol. 42, n. 1, 2003, p. 39-44.

MALDONADO, pe. Manuel Luis. Fénix angrense, vol. 2. Angra do Heroísmo: Instituto Histórico da Ilha Terceira, 1990.

MAXWELL, Keneth. Marquês de Pombal: paradoxo do Iluminismo. São Paulo: Paz e Terra, 1996.

MELLO, Evaldo Cabral de. O nome e o sangue: uma fraude genealógica no Pernambuco colonial. São Paulo: Companhia das Letras, 1989.

MONTEIRO, Nuno Gonçalo. A circulação das elites no império dos Bragança (1640-1808): algumas notas. Tempo, vol. 14, n. 27, 2009, p. 51-67.

NORONHA, Henrique Henriques de. Memórias seculares e eclesiásticas para a composição da história da diocese do Funchal na ilha da Madeira. Funchal: Secretaria Regional do Turismo e Cultura; Centro de Estudos de História do Atlântico, 1996.

OLIVAL, Fernanda $\mathcal{E}$ MONTEIRO, Nuno Gonçalo. Movilidad social en las carreras eclesiásticas en Portugal (1500-1820). In: JIMÉNEZ, F. Chacón \& MONTEIRO, Nuno Gonçalo (coord.). Poder y movilidad social: cortesanos, religiosos y oligarquías en la península Ibérica (siglos XV-XIX). Madri: CSIC, 2006, p. 105-106. 
rev. hist. (São Paulo), n. 175, p. 25-67, jul.dez., 2016 http://dx.doi.org/10.11606/issn.2316-9141.rh.2016.124067
Aldair Carlos Rodrigues \& Fernanda Olival

Reinóis versus naturais nas disputas pelos lugares eclesiásticos do Atlântico português: aspectos sociais e políticos (século XVIII)

OLIVAL, Fernanda. As ordens militares e o Estado moderno: honra, mercê e venalidade. Lisboa: Estar, 2001.

Rigor e interesses: os estatutos de limpeza de sangue em Portugal. Cadernos de Estudos Sefarditas, $\mathrm{n}^{\circ}$ 4, 2004, p. 151-182.

PAIVA, José Pedro. Os bispos de Portugal e do Império (1745-1777). Coimbra: Ed. Universidade de Coimbra, 2006.

RODRIGUES, Aldair Carlos. Clergy, society, and power relations in colonial Brazil: On the vicar forane (vigário da vara), 1745-1800. e-journal of Portuguese History, 13, 1, Providence, jun 2015.

Igreja e Inquisição no Brasil: agentes, carreiras e mecanismos de promoção social. São Paulo: Alameda/ Fapesp, 2014.

RODRIGUES, José Damião. Poder municipal e oligarquias urbanas: Ponta Delgada no século XVII. Ponta Delgada: Instituto Cultural de Ponta Delgada, 1994.

São Miguel no século XVIII: casa, elites e poder, vol. I. Ponta Delgada: Instituto Cultural de Ponta Delgada, 2003.

RUSSEL-WOOD, A. J. Fidalgos e filantropos. A Santa Casa de Misericórdia da Bahia. Brasília: Ed. UNB, 1981.

SANTOS, Antônio Alves Ferreira dos. A Archidiocese de São Sebastião do Rio de Janeiro: subsídios para a história eclesiástica do Rio de Janeiro, capital do Brasil. Rio de Janeiro: Tipographia Leuzinger, 1914.

SCHWARTZ, Stuart. The formation of a colonial identity in Brazil. In: CANNY, N. $\&$ PAGDEN, A. (ed.). Colonial identity in the Atlantic world, 1500-1800. Princeton: Princeton University Press, 1987.

Burocracia e sociedade no Brasil colonial. São Paulo: Perspectiva, 1979.

SILVA, Cândido da Costa. Os segadores e a messe: o clero oitocentista na Bahia. Salvador: Edufba, 2000.

SILVA, Hugo Ribeiro da. O cabido da Sé de Coimbra. Os homens e a instituição (1620-1670). Lisboa: Imprensa do Instituto de Ciências Sociais da Universidade de Lisboa, 2011.

O clero catedralício português e os equilíbrios sociais do poder (1564-1670). Lisboa: CEHR, 2013, p. 93-114.

SILVA, Leandro Ferreira da. Regalismo no Brasil colonial: a Coroa portuguesa e a província de Nossa Senhora do Carmo do Rio de Janeiro (1750-1808). Dissertação de mestrado, FFLCH-USP, São Paulo, 2013.

SILVA, Maria Beatriz Nizza. Ser nobre na colônia. São Paulo: Editora da Unesp, 2004.

SOUZA, Grayce Mayre Bonfim. Para remédio das almas: comissários, qualificadores e notários da Inquisição portuguesa na Bahia colonial. Vitória da Conquista: Edições Uesb, 2014.

SOUZA, Jorge Victor de Araújo. Para além do claustro: uma história social da inserção beneditina na América portuguesa, c. 1580 - c. 1690. Niterói: Eduff, 2014.

Poder local entre ora et labora: a casa beneditina nas tramas do Rio de Janeiro seiscentista. Tempo, v. 32, Revista do Departamento de História da UFF, 2012, p. 69-94.

SOUZA, Laura de Mello e. O sol e a sombra. Política e administração na América portuguesa do século XVIII. São Paulo: Companhia das Letras, 2006. 
TRINDADE, Ana Cristina M. Plantar nova christandade: um desígnio jacobeu para a diocese do Funchal - frei Manuel Coutinho, 1725-1741. Funchal: Drac, 2012.

WEHLING, Arno \& WEHLING, Maria José. Direito e Justiça no Brasil colonial: o Tribunal da Relação do Rio de Janeiro (1751-1808). Rio de Janeiro: Renovar, 2004.

Recebido: 04/02/2016 - Aprovado: 23/09/2016 